\title{
SINKHOLE SUSCEPTIBILITY ASSESSMENT BASED ON MORPHOLOGICAL, IMAGERY, AND CONTEXTUAL ATTRIBUTES DERIVED FROM GIS AND IMAGERY DATA
}

\author{
Xiaomin Qiu', Shuo-Sheng Wu', , , and Yan Chen²
}

\begin{abstract}
This study presents a GIS-based approach to efficiently assess sinkhole susceptibility based on their morphological and contextual attributes derived from GIS and imagery data. Using a 14- $\mathrm{km}^{2}$ karst area in Nixa, Missouri as the study area, we first applied a sequence of GIS operations to extract sinks (i.e., topographic depressions), from bare-ground digital terrain models. We then derived three types of sink attributes from various GIS and imagery data, including four morphological attributes related to sink size, shape, depth, and terrain ruggedness; three imagery attributes denoting the impervious surface percentage, vegetation growth condition, and seasonal water conditions of sinks; and seven contextual attributes related to land use, population density, neighborhood sink density, hydrological flow, groundwater yield, bedrock depth, and historical sinkhole records. Sinks were ranked by each of the 14 attributes and assigned corresponding susceptibility scores, then combined by specified weights. The results identified high-priority sinkholes for mitigation activities or for further field-based inspection. The proposed computerized approach for sinkhole susceptibility ranking can be effectively used as a first-stage sinkhole examination to maximize the use of limited resources for further comprehensive investigation.
\end{abstract}

\section{Introduction}

Sinkholes are common geologic phenomena in karst landscapes where the dominant geological mechanism is the dissolution of soluble rocks, mostly carbonates, rather than mechanical erosion (Gutiérrez et al., 2014). Sinkholes are usually circular to ellipsoidal funnel-shaped depressions on the land surface; the size can be from several centimeters to hundreds of meters, and the depth can be from a few meters to tens of meters (Gutiérrez et al., 2008; Zisman, 2008; Parise, 2010).

While the development of sinkholes involves complex interaction of soil, rock, and groundwater that is unique for each site, two types of sinkholes can be distinguished, including solution sinkholes and subsidence sinkholes (Gutiérrez et al., 2008). Solution sinkholes are created by differential dissolution and lowering of the ground surface where soluble rocks are exposed at or near the surface. Subsidence sinkholes are formed by subsurface dissolution and downward gravitational movement of the cover materials (Gutiérrez et al., 2014).

Subsidence sinkholes can be classified on the basis of the affected materials and the formation processes (Gutiérrez et al., 2008, 2014). The affected materials may include soil cover, non-karst caprock, and karst bedrock; and the formation processes may include collapse, sagging, and suffosion. When the creation of a sinkhole involves more than one material or process, the sinkhole can be described with the dominant material and process followed by the secondary one (e.g., cover sagging and suffosion sinkholes, which are the common type of sinkholes in the study area of this research).

Sinkhole subsidence can cause severe damage to roads and buildings. They also pose threats to human beings and livestock. Assessing sinkhole risk and the potential hazard is critical for hazard mitigation and management (Parise, 2015a; Parise et al., 2015). Hazard analysis can be broadly classified into quantitative, qualitative, and semi-quantitative methods (Lee and Jones, 2004; De León and Carlos, 2006; Van Westen, 2013). The quantitative method aims to quantify the hazard probability or predict losses by deriving numerical expressions of the relationships between hazard parameters and relevant variables. Statistical analysis, such as multiple regression analysis and discriminant analysis, are often applied to build relationship models (Dai et al., 2002). Examples of quantitative analysis includes the studies by Komac (2006), Molina et al. (2010), Sarkar et al. (2010), and Schmidt et al. (2011).

The qualitative method adopts a heuristic approach to estimate potential hazard from relevant factors based on the knowledge and experience of the experts. The method often includes the use of index maps and logical analytical models (Chalkias et al., 2016) and describes hazard risk and vulnerability in qualitative terms, such as high, medium, and low (De León and Carlos, 2006). Examples of qualitative analysis include the studies by Barredo et al. (2000), Van Westen et al. (2003), and Abella and Van Westen (2008).

The semi-quantitative method hazard analysis estimates potential hazard by converting hazard variables into indices and combining them based on the weights determined by expert judgement (Nsengiyumva et al., 2018). The

\footnotetext{
${ }^{1}$ Department of Geography, Geology and Planning, Missouri State University

${ }^{2}$ School of Environmental Sciences and Engineering, Donghua University, Shanghai, China

c Corresponding author: sw1020@gmail.com
} 
combined hazard values may be further divided into different numbers of classes to be used for different purposes (Abella and Van Westen, 2008). This method often requires varied degrees of grouping, standardizing, indexing, and weighting for input variables. Example of semi-quantitative analysis include the studies by Peduzzi et al. $(2005,2009)$, Abella and vanWesten (2007), Wati et al. (2010), Feizizadeh and Blaschke (2014), Chalkias et al. (2014, 2016), and Nsengiyumva et al. (2018).

As this study adopts a semi-quantitative hazard analysis method, the advantages and limitations of this method are discussed in more detail. The main advantage of the semi-quantitative method is that it can reasonably rely on existing datasets and does not require costly field data as needed for the quantitative method (Anderson, 2013; Nsengiyumva, 2018). Furthermore, by using the grouping and weighting approach, qualitative and categorical data can be conveniently incorporated and combined with quantitative information.

One problem with the semi-quantitative method is the high degree of simplification in grouping and indexing procedures (Dai et al., 2002). Another limitation is the subjectivity of weightings and the reproducibility of results (Anderson, 2013). Specifically, since the determination of variable weights relies on expert knowledge, it is difficult to test the relative efficacy of one expert's weightings over the other's, and the chosen weightings would have limited reproducibility.

A major difference between this study and other semi-quantitative hazard studies is that this study explicitly considers the quality of the spatial datasets for deriving hazard variables in determining suitable variable weights, in addition to taking hazard implication of the variables into account. Specifically, as our hazard variables are all derived from GIS and imagery data, the precision/quality of spatial data plays an important role in the reliability of the derived variables for predicting hazard. While past semi-quantitative studies often only consider hazard implication of variables in determining their weights, this study contributes to the field of hazard analysis by explicitly accounting for spatial data quality in the weighting procedures.

It is worth noting that the terms susceptibility assessment and hazard assessment may be explicitly differentiated. Specifically, susceptibility assessment indicates the relative probability of sinkhole incidence without referring to any time interval, while hazard assessment provides a quantitative measure of such probability within a time interval (Gutiérrez et al., 2008b; Galve et al., 2009a). In other words, the generic concept of susceptibility describes the potential that a sinkhole incidence may occur in a certain area in an infinite time interval (Taheri et al., 2015; Ciotolia et al., 2016). As this study does not analyze sinkhole data of different time intervals, we will use the term susceptibility assessment instead of hazard assessment for the rest of the article.

Traditionally sinkholes are identified through field-based investigation by probing/boring activities (Zisman, 2001; Bullock and Dillman, 2003; Del Prete et al., 2010; Festa et al., 2012), area reconnaissance (Thomas and Roth, 1999) and geophysical applications (Krawczyk et al., 2012; Kaufmann, 2014). Large-scale sinkhole mapping may be accomplished by examining existing topographic maps or geologic maps and digitizing geologic features (Applegate, 2003; Gutiérrez et al., 2008; Galve et al.; 2009b). However, the results may lack the desired precision due to low resolution of the maps (Brinkmann et al., 2008; Basso et al., 2013). The reliability of this approach that digitizes features from existing maps also depends on the drafter's experience (Angel et al., 2004).

The advancement of digital photogrammetry and laser altimetry, particularly the improved data resolution, has increased the capability of sinkhole detection (Atzori et al., 2015; Intrieri et al., 2015; Al-Halbouni et al., 2017; Zumpano et al., 2019). The conventional approach is to delineate sinkholes through visual interpretation of digital imagery (Reese and Kochanov, 2003; Seale et al., 2008), while many studies have explored automatic approaches for extracting sinkholes or modeling sinkhole susceptibility (Zhu et al., 2014; Wall et al., 2017; Zumpano et al., 2019). For example, Stocks (2007) used an object-based approach to classify pixels of digital photos as sinkholes, by first grouping image pixels into meaningful objects of different hierarchies based on similar pixel statistics, and then classifying hierarchical objects into different land classes through iterated training processes. Galve et al. (2008) used a digital image classification approach to classify areas of different sinkhole susceptibility based on 27 geomorphologic, hydrogeological, and human factors derived from existing GIS data. Lamelas et al. (2008) used logistic regression to map sinkhole probability based on a variety of lithological, stratigraphic, geomorphological, and hydrological variables, as well as anthropogenic variables relevant to locations of man-made facilities. Siart et al. (2009) extracted sinkholes based on spectral values of satellite images; they then refined the results based on pre-defined size, slope, and elevation criteria for sinkholes.

Since the study area is situated in a hilly and vegetated karst terrain where field investigation is particularly labor-intensive and time-consuming, we propose a computerized assessment approach suitable for this type of landscape, and focus on sinkhole attributes that can be efficiently derived from common GIS and imagery data, including digital terrain models (DTMs), digital aerial photos, land parcel data, census population data, and well data. Specifically, four of the adopted sinkhole attributes are suitable for a hilly and vegetated landscape, including a terrain ruggedness index, a hydrological flow accumulation statistic, the Normalized Difference Vegetation Index (NDVI), and the seasonal surface water condition. 
In addition to presenting a computerized assessment approach suitable for a hilly, vegetated karst terrain, and adopting sinkhole attributes that can be conveniently derived from common GIS and imagery data, this study contributes to sinkhole research by proposing three sinkhole attributes as hazard indicators that have not been used in past sinkhole susceptibility analyses. The three pioneering attributes are the terrain ruggedness index, the maximum hydrological flow accumulation, and the NDVI.

\section{Study Area}

An area approximately $14 \mathrm{~km}^{2}(3.5 \mathrm{~km}$ by $4 \mathrm{~km})$ in the northwest suburb of the city of Nixa, Missouri (Fig. 1), is used to demonstrate the methodology for sinkhole extraction and hazard assessment. The Nixa area is situated in the physiographic region of Springfield-Salem Plateaus that has a well-developed karst topography. The karst plateau is underlain by coarse-grained fossiliferous Mississippian-aged limestone and cherty limestone. Situated in a humid subtropical climate with overlying surficial soil up to 12-meter thick (Stohr et al., 1981), the region has hundreds of caves, springs, and sinkholes, with cover sagging and suffosion types of sinkholes most common.

The Nixa area sits on the drainage divide between the Finley River and the James River (Fig. 1). Flooding after heavy rain makes this area susceptible to erosion. Porter and Thomson (1975) documented a total of 266 sinkholes in the Nixa karst area. The current sinkhole database at Missouri Department of Natural Resources has approximately 300 sinkhole records, but only about three dozen are collapse sinkholes (Kaufmann, 2007; Gouzie and Pendergrass, 2009).

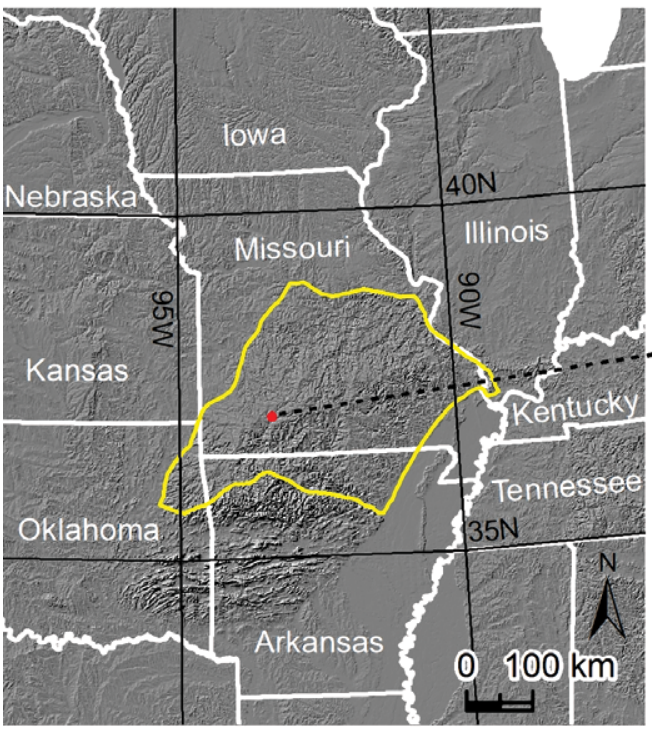

The Nixa study area

\section{Springfield-Salem Plateaus}

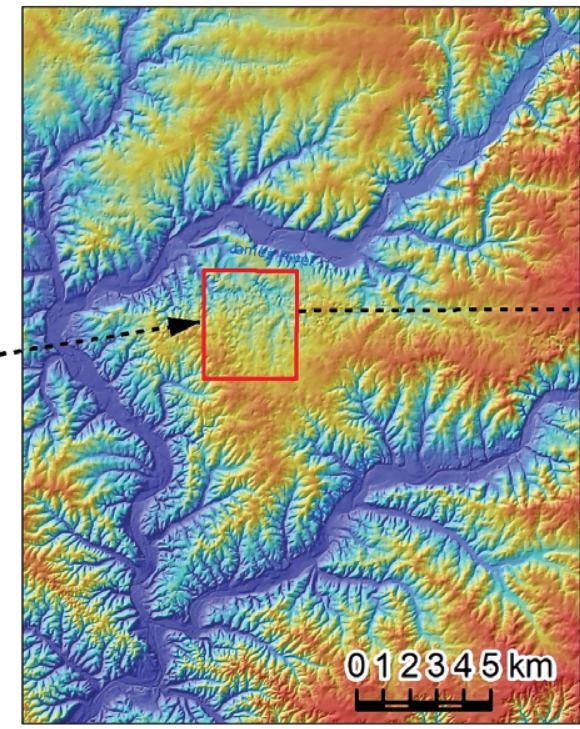

Elevation (Meter)

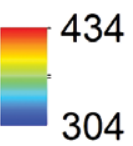

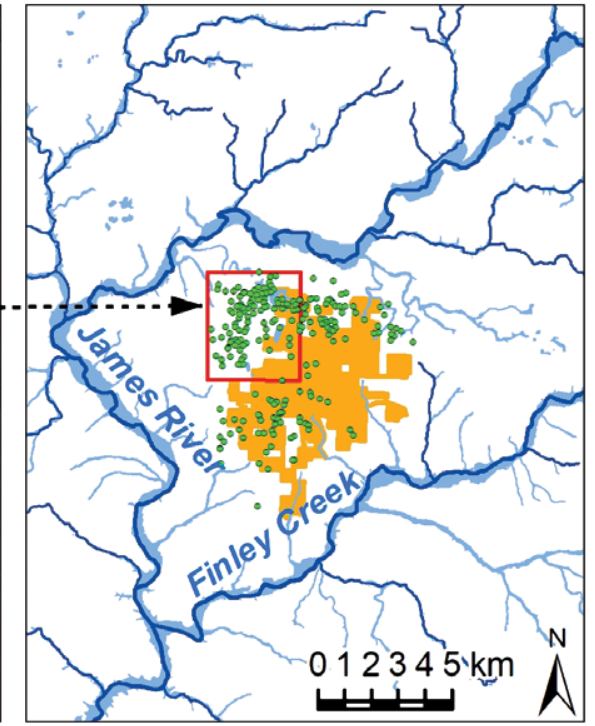

- MoDNR sinkholes

\section{City if Nixa}

Floodplain

Figure 1. The Nixa study area (red rectangle) in the physiographic region of Springfield-Salem Plateaus (yellow polygon), with a hill-shaded relief map showing the topography (middle map), and a drainage map showing documented sinkholes in the area (right map).

\section{Data Source}

Data used in this study include DTMs, digital aerial photos, land use, building footprints, population, wells, and historical sinkhole data for the Nixa area. Firstly, we obtained bare-ground DTMs of one-meter spatial resolution from the U.S. Geological Survey (USGS) center at Rolla. The DTMs are originally derived from LiDAR remote-sensing data that were collect in 2006 and have been processed to remove vegetation and building points. The DTMs have a vertical accuracy of about $30 \mathrm{~cm}$ and a horizontal accuracy of about $50 \mathrm{~cm}$. The DTMs will be used to extract sinks and to calculate the terrain ruggedness index and the hydrological flow accumulation for indicating potential sinkhole hazard.

We downloaded digital aerial photos of 3-band, 0.6-m resolution, taken during the winter of 2008 from the Missouri Spatial Data Information Service website (http://www.msdis.missouri.edu/). The 2008 photos will be used to derive seasonal water conditions during the winter and to compute impervious surface percentages, which will be used to infer human accessibility. We also downloaded digital aerial photos of four-band, one-meter resolution, taken during 
the summer of 2009 from USGS The National Map website (http://nationalmap.gov). The 2009 photos will be used to derive seasonal water conditions during the summer and to calculate a vegetation growth index for indicating potential sinkhole hazard.

We obtained parcel zoning data from the Department of Planning and Development at Christian County, Missouri. The zoning data will be used to determine land uses for the areas where sinks are located. We downloaded building footprints data from ESRI ArcGIS Online (https://www.arcgis.com). The building footprints data, originally generated by Microsoft, will be used to refine/redistribute census block-level population from 2010 block-level population data from the U.S. Census Bureau American FactFinder website (https://factfinder.census.gov). The population data will be used to derive population density for the neighborhood area of sinks for indicating human exposure to potential sinkhole hazard. We further downloaded wells data and historical sinkhole data from Missouri Spatial Data Information Service. The wells data will be used to calculate a sinkhole risk measure based on the well yield (gallons per minute), and the historical sinkhole data will be used to calculate a sinkhole density measure to infer future hazard potential.

\section{Analysis Methods}

We used the per field classification technique in remote sensing (Wu et al., 2009) to derive attributes for sink polygons. The per field technique is commonly used for land use or land cover classification, in which areas within pre-determined polygonal fields are considered homogeneous and are classified based on relevant attributes of the fields (Aplin et al., 1999; Geneletti and Gorte, 2003). In this study, we used sink-depth isolines or their buffered areas as field boundaries for calculating the morphological, imagery, and contextual statistics for sinks.

In the following sections, we first describe the approach used for extracting sinks from DTMs using common GIS tools. We then explain the methods for deriving three types of sink attributes (Table 1) for sinkhole susceptibility assessment. Note that some of attributes are considered important in the sense of indicating human vulnerability to potential sinkhole incidences, instead of indicating the probability of geological activities of sinkholes (e.g., the rapid movement of soil cover).

Table 1. The three types of sink attributes and the used methods to assess the attributes.

\begin{tabular}{|c|c|c|}
\hline Types & Attributes & Assessment Methods \\
\hline Morphological & $\begin{array}{l}\text { 1. Size } \\
\text { 2. Shape complexity } \\
\text { 3. Depth to diameter ratio } \\
\text { 4. Terrain ruggedness }\end{array}$ & $\begin{array}{l}\text { 1. Larger size } \rightarrow \text { higher sinkhole susceptibility } \\
\text { 2. Higher shape complexity } \rightarrow \text { higher sinkhole susceptibility } \\
\text { 3. Larger depth/diameter } \rightarrow \text { higher sinkhole susceptibility } \\
\text { 4. More rugged } \rightarrow \text { higher sinkhole susceptibility }\end{array}$ \\
\hline Imagery & $\begin{array}{l}\text { 1. Impervious surface } \% \\
\text { 2. NDVI } \\
\text { 3. Seasonal water condition }\end{array}$ & $\begin{array}{l}\text { 1. Higher impervious surface } \% \rightarrow \text { higher sinkhole susceptibility } \\
\text { 2. Lower NDVI } \rightarrow \text { higher sinkhole susceptibility } \\
\text { 3. Impounded water } \rightarrow \text { lower sinkhole susceptibility }\end{array}$ \\
\hline Contextual & $\begin{array}{l}\text { 1. Land use } \\
\text { 2. Population density } \\
\text { 3. Hydrological flow accumulation } \\
\text { 4. Sink density } \\
\text { 5. Sinkhole record density } \\
\text { 6. Well yield } \\
\text { 7. Bedrock depth }\end{array}$ & $\begin{array}{l}\text { 1. Commercial \& residential land uses } \rightarrow \text { higher sinkhole susceptibility } \\
\text { 2. Higher population density } \rightarrow \text { higher sinkhole susceptibility } \\
\text { 3. Higher hydrological flow } \rightarrow \text { higher sinkhole susceptibility } \\
\text { 4. Higher sink density } \rightarrow \text { higher sinkhole susceptibility } \\
\text { 5. Higher sinkhole record density } \rightarrow \text { higher sinkhole susceptibility } \\
\text { 6. Higher well yield } \rightarrow \text { higher sinkhole susceptibility } \\
\text { 7. Deeper bedrock } \rightarrow \text { lower sinkhole susceptibility }\end{array}$ \\
\hline
\end{tabular}

\section{Extracting Sinks from Bare-Ground DTMs}

A sequence of GIS tools in ArcGIS software 10.4 is used to extract topographic depressions from the bare-ground DTMs. Specifically, we first filled the hydrological depressions on a DTM clipped to the study area. All depressions, regardless of depth, were filled in this process. Understanding that not applying a depth threshold at this stage of analysis would result in large amount of small and possibly artificial sinks being derived in later processes (Zhu et al., 2014; Qiu and $\mathrm{Wu}, 2017$ ), we intended to later examine the size-distribution of the derived hydrological sinks to gain insight of the topography. The information will help decision making in selecting a suitable size threshold for filtering out reasonable sinks.

After creating the sink-filled DTM, we subtracted the smooth-surface DTM with the original bare-ground DTM to derive a sink-depth DTM (Figure 2). Sink-depth isolines of $50 \mathrm{~cm}$ were then computed from the sink-depth DTM, considering that the original DTM has a vertical accuracy of about $30 \mathrm{~cm}$ and the equivalent contour interval would be approximately $50 \mathrm{~cm}$ (USDA, 2011). Lastly, we converted the $50 \mathrm{~cm}$ sink-depth isolines to polygons, so they can be used as the field boundaries for deriving sink attributes. A total of 830 sinks were extracted for the study area.

We noted that there is one particularly large and irregularly-shaped sink in the north-east quadrangle of the study 

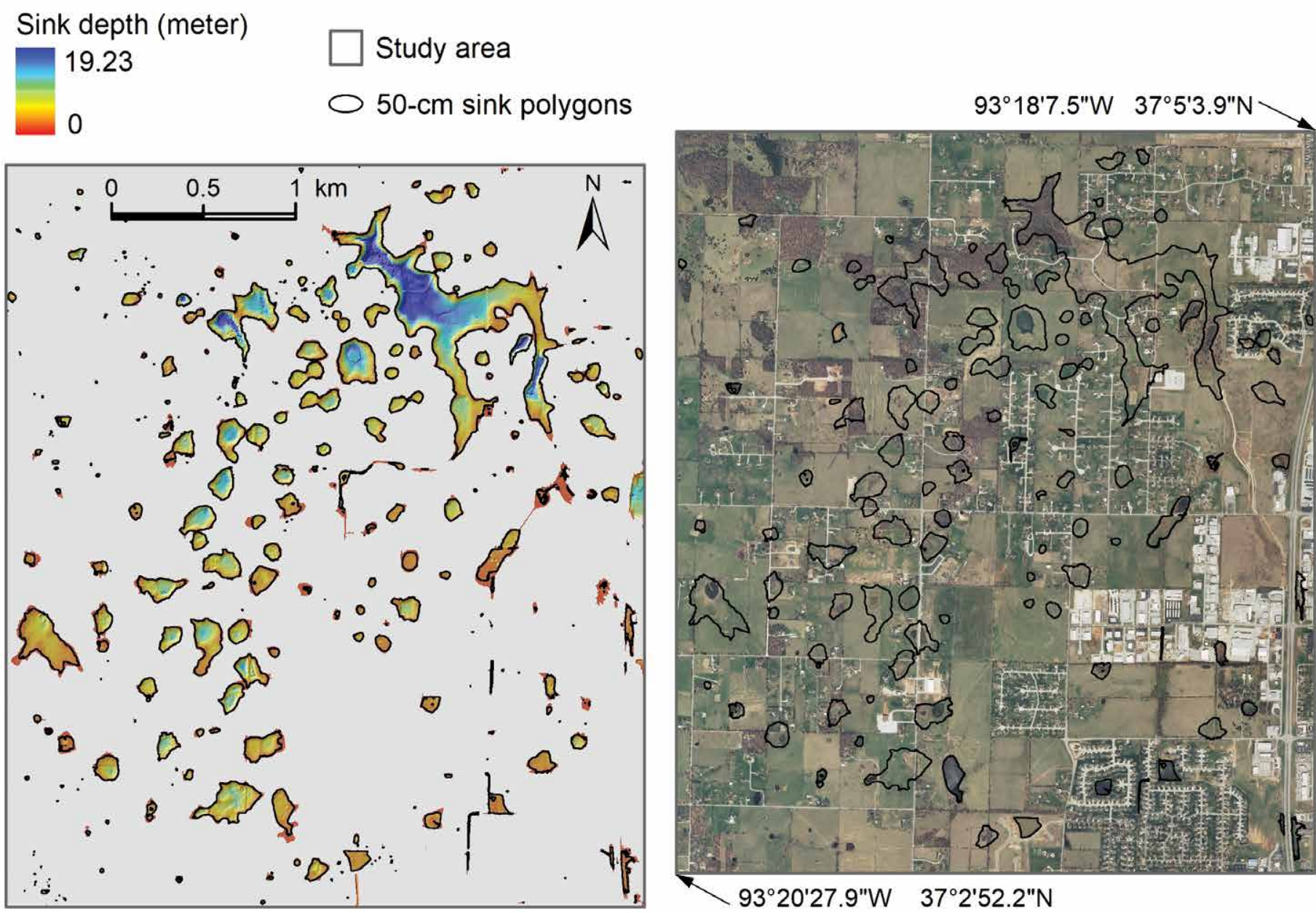

Figure 2. A hill-shaded sink-depth DTM with $50 \mathrm{~cm}$ depth sink polygons (left), and corresponding aerial photos with large sink polygons displayed (right).

area that contains varied landscape (Fig. 2). Although some part of this sink may be formed by a combination of geological and human factors, this outlier sink is excluded for further assessment so that we can focus on other sinks for classifying and comparing their attributes.

We also noted that a large portion of sinks are quite small (237 out of the 830 sinks are less than $1 \mathrm{~m}^{2}$ ). Understanding that the sinks were extracted from $1 \mathrm{~m}$ DTMs, and the minimum data resolution for detecting a landscape object should be less than one-half the size of the feature (Jensen, 2005), we regard sinks smaller than $3 \mathrm{~m}^{2}$ unreliable and possibly artifacts. Therefore, a total of 362 small sinks were removed and the remaining 468 sinks were retained for continued assessment. An initial examination of the sinks on aerial photos indicate some sinks appear to be man-made detention ponds in residential neighborhood areas (Fig. 2). This issue will be addressed later in our analysis.

\section{Assessing Sinkhole Susceptibility based on Sinks Morphological Attributes}

We first assessed sinkhole susceptibility relevant to sink area/size (Fig. 3A). As sinkholes develop and evolve, they are likely to expand in size and in depth until the underground crevices and voids are clogged and the overlying materials stop moving downward (Gouzie and Pendergrass, 2009; Parise, 2010; Gutierrez et al., 2014). Based on this sinkhole development process, smaller sinkholes seem to have more potential for continued growth and threatening human activities and properties, while large sinkholes may have evolved to a mature stage of development, and therefore, pose little risk to humans. Nevertheless, there is no direct relationship between sinkhole size and its potential for further development. In addition, we can never be certain what stage of development a sinkhole is at present. As a result, sinkhole susceptibility is assessed based on potential human exposure corresponding to the size of a sink. From a management point of view, larger sinks likely require more manual efforts for mitigation actions. For these reasons, higher susceptibility scores are assigned to sinks of larger size, which will be described in detail later.

We noticed that a few sinks in the south-east quadrangle of the study area have considerably jagged and elongated shapes (Fig. 2B). A close examination of current and historical aerial photos indicates that these irregularly-shaped sinks are man-made roadside swales and subdivision detention basins. To filter out these man-made sinks, we applied 
(A) Sink size $\left(1000 * \mathrm{~m}^{2}\right)$
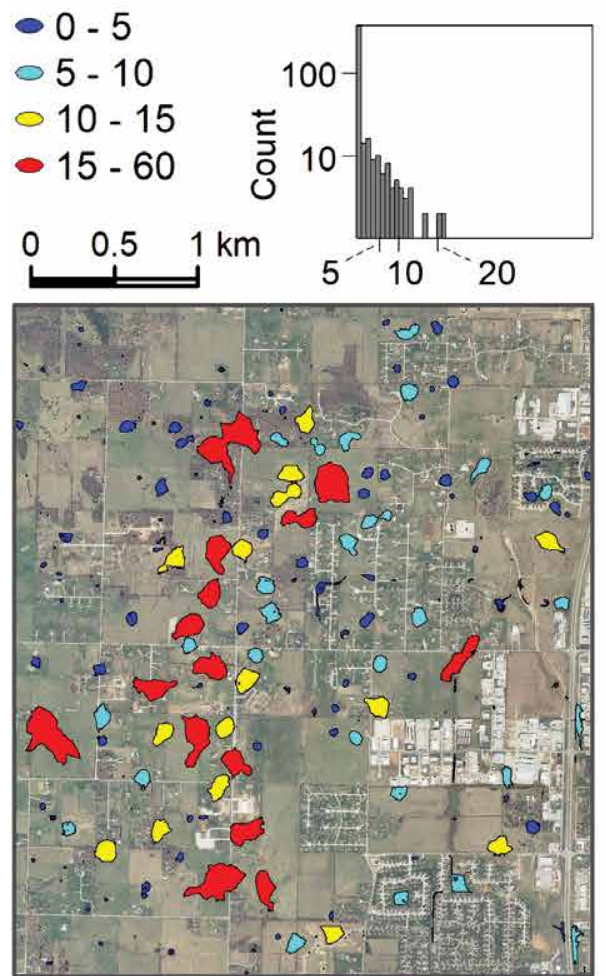

(B) Sink shape complexity
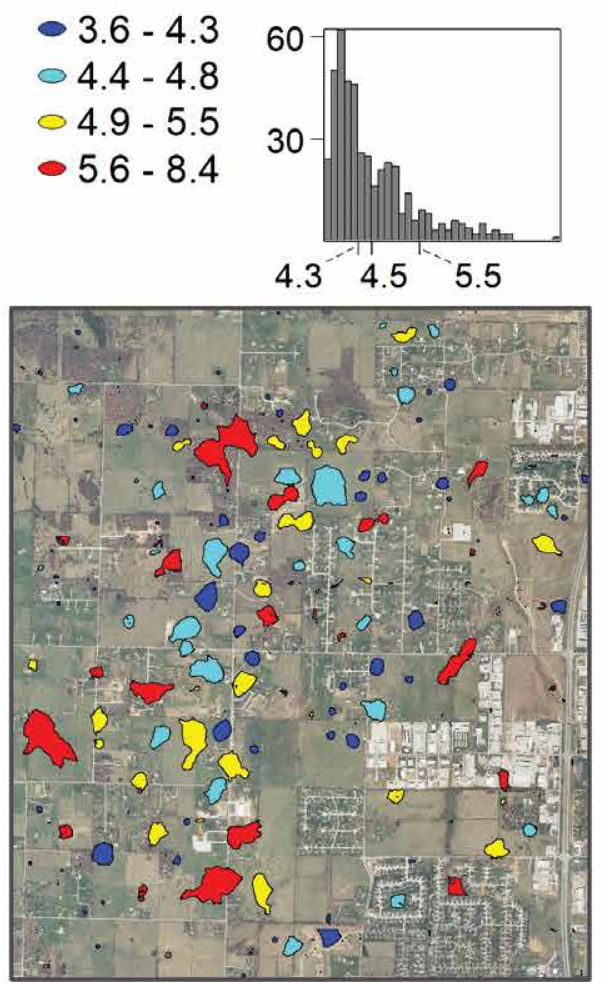

(C) Sink depth-diameter ratio

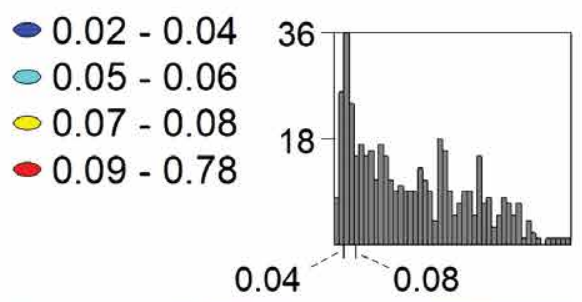

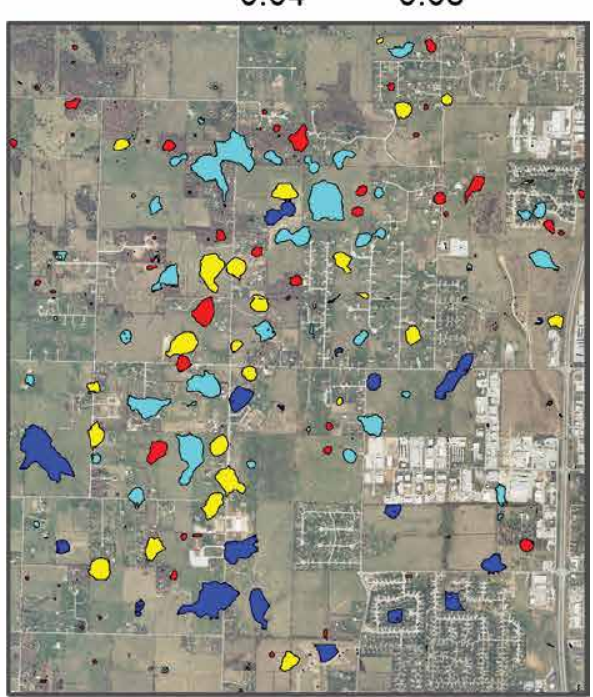

Figure 3. Ranking of sinks based on size $(A)$, shape complexity $(B)$, and depth to diameter ratio $(C)$, with histograms showing the distributions.

a shape complexity index, calculated as the polygon perimeter divided by the square root of polygon area (Moser et al., 2002). A more complex shape will have a higher shape complexity index. Man-made sinks have a shape index larger than 7.4, therefore, a threshold of 7.4 is applied to exclude a total of 18 man-made sinks.

Some neighborhood detention ponds (e.g., sinks in the southwest and northeast corners of the study area) have relatively compact shapes. In contrast to jagged, elongated detention basins, these compact-shaped detention ponds may possibly have a geological origin but have been utilized for storm-water management purposes. For this reason, these compact-shaped detention ponds are retained for subsequent assessment. Mapping the remaining 450 sinks based on the shape complexity index (Fig. 3B), we noted that larger sinks tend to have more irregular shapes than smaller sinks. For sinkhole management purpose, sinks of more irregular shapes have boundaries harder to delineate in the field and would require more work for mitigation actions, e.g., putting up warning signs around the perimeter. For this reason, we consider sinks of more irregular shapes posing more risk to humans and would give them a higher sinkhole susceptibility score.

Most sinkholes are depressions with gentle slopes and smoother morphology formed by the sagging or suffosion process; and sinkholes with steep sides formed by the collapse process are relatively uncommon (Troester et al., 1984; Denizman, 2003; Caramanna et al., 2007; BGS, 2017). Sinkhole morphology is mainly determined by the mechanical strength of the surface materials in which they form. For example, sinkholes formed in alluvial sediment will have higher slopes and greater depths than sinkholes formed in mud (Al-Halbouni et al., 2017). Margiotta et al. (2012) indicated that cover collapse sinkholes are often steep with a diameter/depth ratio from 1.5 to 3 . As the collapse process is considered relatively dangerous due to the rapid movement of surface materials, a higher susceptibility score is assigned to sinks with a larger depth to diameter ratio. For the study area, we noted that sinks with a higher depth/diameter ratio tend to be smaller in size and more compact in shape (Fig. 3C).

We further examined the topography of sink surfaces. Considering that sink surface is affected by the underlying geological structure, the terrain conditions may inform recent raveling activities that can facilitate surface water transport of soil down into cavities in underlying bedrock. As a result, sinks with a rougher surface are considered likely more geologically active than sinks with a smoother surface.

We created cross-sectional profiles for sinks to examine their terrain conditions (Fig. 4, left), and further derived a terrain ruggedness index to quantify the surface disturbing degree (Fig. 4, right). Specifically, the standard deviation of 
-.-.- Cross section lines

Sink depth (meter)

19.23

0

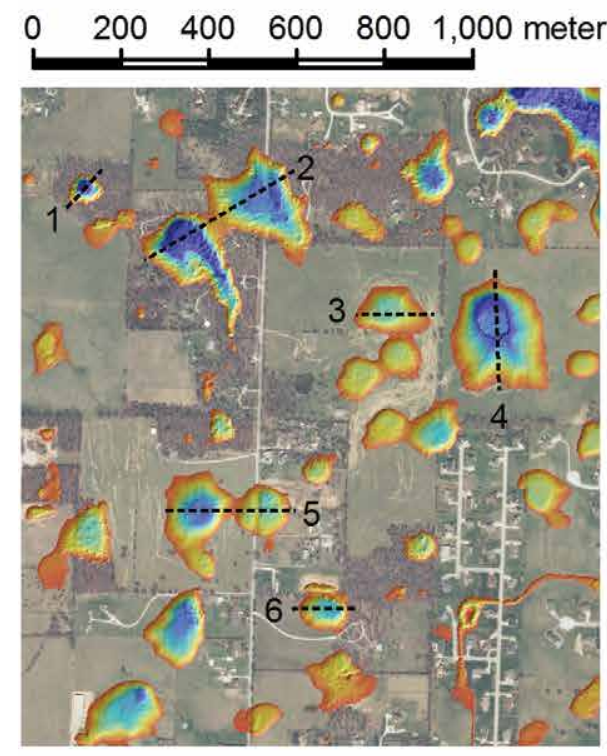

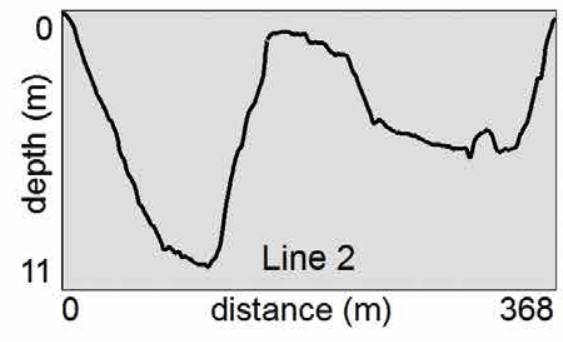
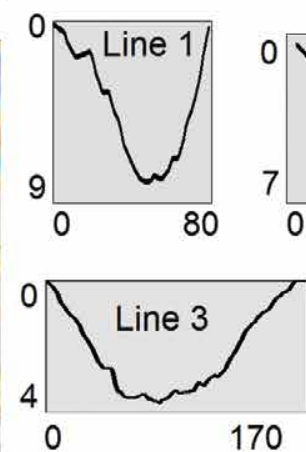

170
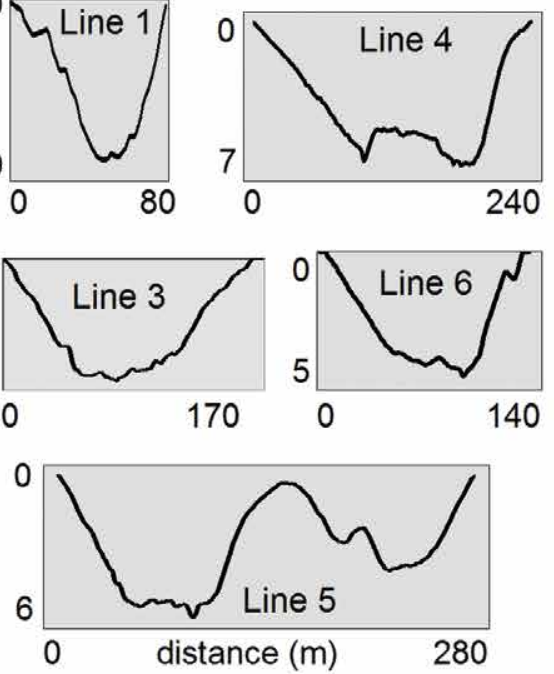

Sink terrain ruggedness index

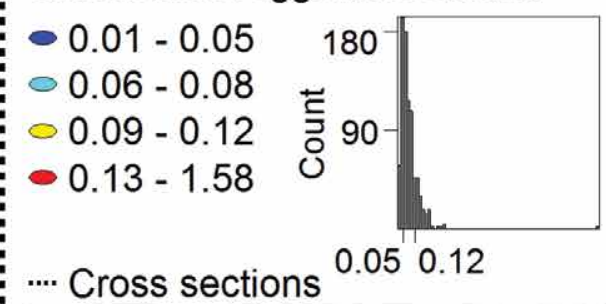

butions (right).

elevation in a $3 \times 3 \mathrm{~m}$ moving window was first computed as the local terrain ruggedness index (Ascione et al., 2008). The average terrain ruggedness index within each sink polygon was then calculated as an attribute. Observe that sinks with a high ranking of terrain ruggedness index also have a relatively rugged profile (Fig. 4).

Some sinks (represented by $0.5 \mathrm{~m}$ depth isolines) appear to be congregations of two original sinks (Fig. 4). This phenomenon happens when sinks grow and expand throughout the years and eventually connect with neighboring sinks to form a large one. Sink coalescence would have some effects on the terrain ruggedness measure. Specifically, the connecting ridge area of two neighboring sinkholes are generally broader and less disturbed/rugged than the sloping area. As a result, when two neighboring sinks are connected, the local terrain is likely to become smoother. The new terrain ruggedness index for the congregated sink would be approximately an average of the two original ones.

\section{Assessing Sinkhole Susceptibility based on Sinks Imagery Attributes}

Many sinks in the study area are traversed by roads (Fig. 2). Since roads provide human accessibility, sinks close to roads would pose more sinkhole risk than sinks away from roads. Accordingly, we derived impervious surface percentages for sinks to indicate the human exposure level (Qiu and Wu, 2017). A raster layer of impervious surface was first generated through remote sensing imagery classification from the $0.6 \mathrm{~m}$ resolution aerial photos. The percentage of impervious surface within a 100-meter buffer of sink polygons was then calculated for each sink (Fig. 5A). Sinks with a higher impervious surface measure ratio will be given a higher susceptibility score.

Because sinks naturally accumulate water, there is often more vegetation growth around sinkholes than in surrounding areas (Handfelt and Attwooll, 1988; Sowers, 1996; Gutiérrez et al., 2008). And since vegetation stabilizes soil, sinkholes would be safer when there is denser vegetation nearby (Gutiérrez et al., 2008; Zhou and Beck, 2008). For example, because trees stabilize soil more effectively than grass does, sinks within woodlands pose less risk than those in grasslands. Also, grassland is more accessible to humans than woodland, which makes sinks located there potentially more unsafe to a greater number of passers-by. In the same way, sinks located on barren land are potentially more likely to cause the most problems.

Accordingly, we calculated the NDVI index in order to gauge vegetation growth conditions. The NDVI measures the chlorophyll pigment absorptions in the red band and the high reflectivity of plant materials in the near-infrared (NIR) band (ESRI, 2016). Such values were interpreted as shown in Table 2 (Weier and Herring, 2000). 
(A) Impervious surface \%
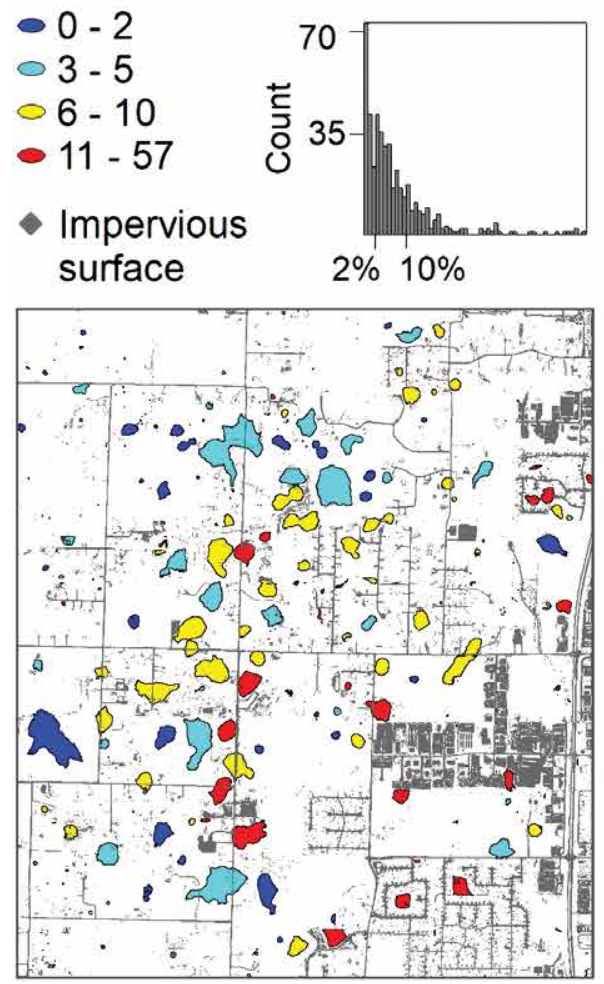

(B) NDVI

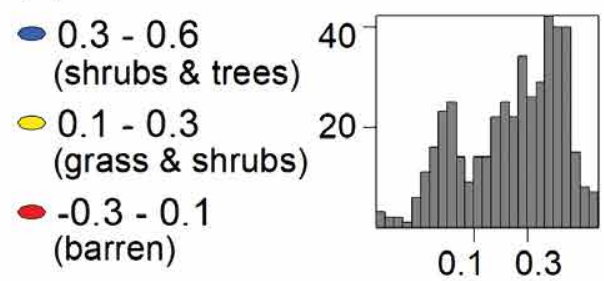

(C) Seasonal water condition

- constant wet

(82 out of 450 sinks)

0 intermittent

(12 out of 450 sinks)

- constant dry

( 356 out of 450 sinks)
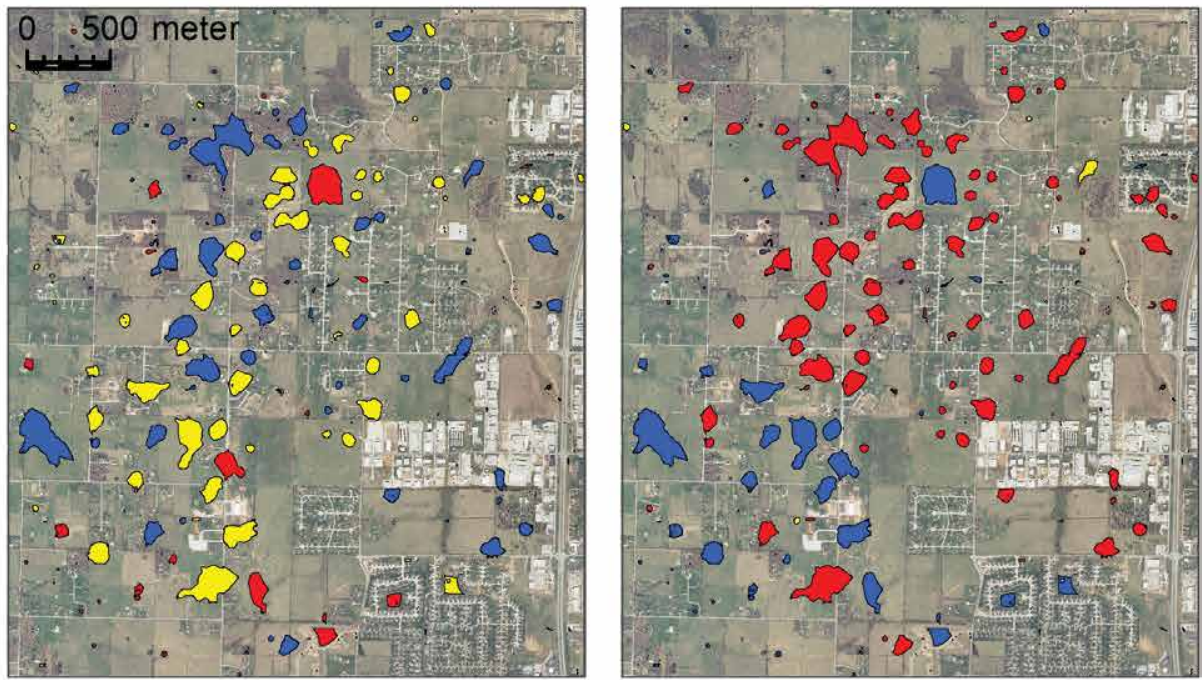

Figure 5. Ranking of sinks based on impervious surface percentage (A), NDVI (B), and seasonal water condition (C), with histograms showing the distributions.

Table 2. Interpretation of NDVI values.

\begin{tabular}{cc}
\hline Value & Interpretation \\
\hline$<0.1$ & rock, sand, snow \\
$0.2-0.3$ & shrubs, grassland \\
$0.6-0.8$ & temperate and tropical rainforests \\
\hline
\end{tabular}

We derived a NDVI raster layer from the one-meter, 4-band, 2009 aerial photos. The average NDVI value within each sink polygon was then calculated as its attribute (Fig. 5B). Sinks having a lower NDVI are considered having higher sinkhole susceptibility.

Many sinks in the study area have impounded water that can be observed from aerial photos (Fig. 2). As water

is a triggering mechanism for sinkhole incidence (Parise, 2010, 2015b; Kaufmann and Romanov, 2016), the surface water seasonal condition can inform potential sinkhole risk by showing whether the surface water can be easily flushed down into the bedrock or soil voids and how clogged the underground voids are (Qiu and Wu, 2017).

Three types of surface water conditions can be observed for sinks in our study area:

1. Sinks with perennially impounded water, which may be considered as a relatively inactive sinkhole with sinkhole throat clogged;

2. Sinks with seasonal surface water, which may indicate water slowly drains down sinkhole throats that are not completely clogged; and

3. Sinks that are constantly dry, which may indicate that the surface water can quickly drain out from the sinkhole throat.

A water-impounded sink may be a sagging or suffosion sinkhole that grows from top down, or a collapse sinkhole that grows from bottom up. In the latter case, surface water is temporarily retained due to an earlier collapse clogged the sinkhole throat. As the water-filled collapse sinkhole may continue to grow further, the growth becomes slower and the potential risk is reduced.

In this study, we focused on the water retaining mechanism for sagging/suffosion sinkholes for susceptibility assessment, since collapse sinkholes are relatively rare in the study area. Specifically, constantly dry sinks are considered posing the most potential sinkhole risk due to the constant transportation of water from surface to underground that expedites the dissolution process. In contrast, water-filled sinks have relatively inactive water flow and are considered posing less risk than (intermittently) dry sinks. From another point of view, the impounded surface water allows progressive geologic activities (e.g., rapid soil/rock movements), to be easier to detect, and thus, makes the water-filled sinks more manageable. 
To derive the seasonal water condition for sinks, we classified the water cover class from both the 2008 winter aerial photo and the 2009 summer aerial photo. As winter is the dry season (an average rainfall of $196 \mathrm{~mm}$ ) and summer is the wet season (an average rainfall $299 \mathrm{~mm}$ ) in Nixa, Missouri, the water cover classes from the two seasons were compared, and sinks were categorized as either constantly dry, intermittently dry, or constantly wet (Fig. 5C).

\section{Assessing Sinkhole Susceptibility based on Sinks Contextual Attributes}

What type of land use a sink is located has implications in human exposure to potential sinkhole incidence. For example, commercial land use usually has more human activities than other land uses; therefore, sinks located on commercial land use are considered to pose higher potential sinkhole risk. In contrast, sinks on agricultural or manufacturing land use often have the least traffic and thus present the least risk to humans.

To assess sinkhole susceptibility based on land use, we used parcel data to infer land use information for sinks. Land parcels were categorized into four land use types, including commercial, agricultural/manufacturing, and two types of residential land use: rural and suburban (Fig. 6A). For the two residential land use, suburban residential is considered to have more human activities/traffic and, therefore sinks located on it would pose higher human threats. When a sink falls on more than one land use, the land use occupying more sink surface takes priority over others.

(A) Parcel land use

$\square$ Agricultural/Manufacturing

$\square$ Rural residential

$\square$ Suburban residential

Commercial

\section{$\backsim$ Sink polygons}

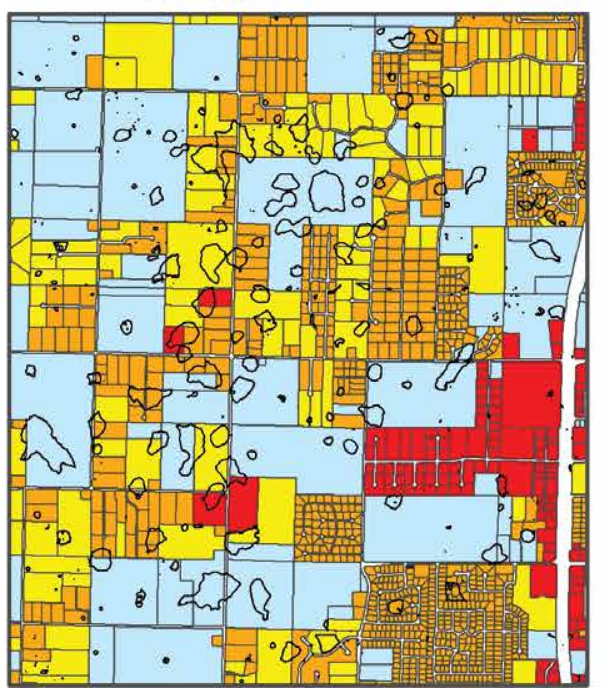

(B) Estimated population by building footprint

185

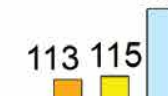

37

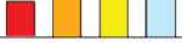

\# of sinks

0.0

$0.1-2.0$

$2.1-3.0$

$3.1-6.6$

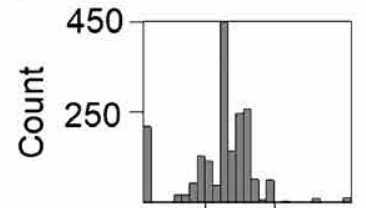

c3 Sink polygons

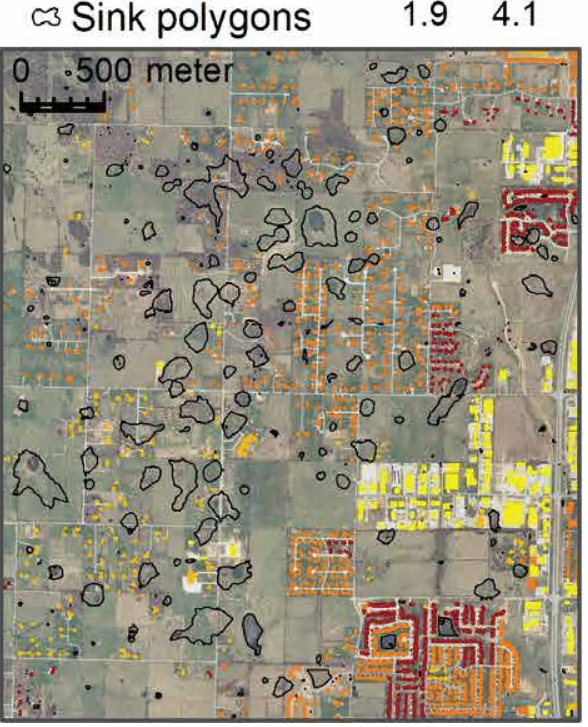

(A) Flow accumulation ( ${ }^{\star} 100$ square meters)

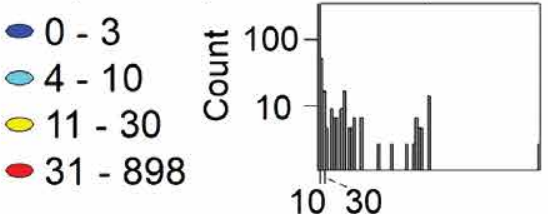

$\sim$ Hydrological drainages

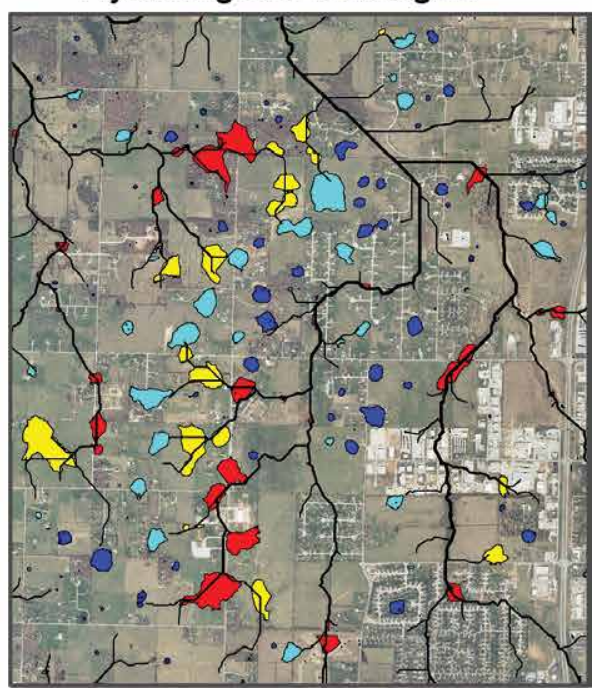

Figure 6. Four types of parcel land use with a chart showing the number of sinks in each land use (A), redistributed census block populations based on land use types and building footprints (B), and ranking of sinks based on hydrological flow accumulation (C), with histograms showing the distributions.

In addition to land use types, population density for the nearby area of sinks has implications in human exposure to potential sinkhole incidence. Therefore, sinks with higher population density are considered to pose more sinkhole threats to humans than sinks with lower population density.

We calculated the population density within a 400-meter buffer of sink polygon to infer neighborhood population density for sinks. The reason a 400 -meter $(0.25$ miles, about 5 -minute walk) buffer is used to calculate population density is that this distance is widely used as an acceptable walking distance in many studies (Atash, 1994; Krizek, 2003; McCormack et al., 2008). The calculation was performed in the following three steps:

1. Using the dasymetric mapping approach to redistribute block-level population to residential buildings, based on building footprints and land use data with predefined population ratios for different land uses (Fig. 6B).

2. Calculating the total population within a 400-meter buffer of each sink polygon by summing the building populations within the buffer.

3. Calculating population density for the buffered area and assigning the measure to respective sinks. 
We further examined the hydrological flow for sinks to assess sinkhole susceptibility. Since sinks with larger accumulated flows would have more water supply to facilitate the progressive geological process, they are considered to have higher risk than sinks with smaller accumulated flows.

To calculate the accumulated flow for sinks, we first filled the hydrological depressions on a 10-m DTM resampled from the $1 \mathrm{~m}$ DTM to generate a smooth surface so that the subsequent flow direction calculation will be more accurate. A flow direction raster was then derived with the cells values representing one of the eight possible flow directions from the center cell to the neighboring cell with the steepest descent. A flow accumulation raster was further derived with the cell values representing the total number of upslope cells flowing into each downslope cell. Lastly, the maximum accumulated flow value within each sink polygon was calculated, which can be seen as the water catchment areas for the lowest point of the sink.

We noted that sinks situated on hydrological drainages naturally have high flow accumulations (Fig. 6C). Sinks located in the general downstream areas (the north) do not necessarily have larger flow accumulation than sinks located in upstream areas (the south), because the most important factor for determining a sink's flow accumulation is whether the sinks is situated within a drainage valley, which depends on local topography around the sink.

Another contextual attribute that this study incorporated for sinkhole susceptibility assessment is the density of neighboring sinks, since locations with a high density of sinks are prone to sinkhole incidence (Galve et al., 2009c). We calculated the density of neighboring sinks within a 400-m buffer of the sink of interest to indicate the degree of sinkhole susceptibility (Fig. 7A). There appears to be high density of sinks in the north-central area (shown as red).

Existing sinkhole records may provide insight to potential sinkhole risk. Using the sinkhole database compiled by the Division of Geology and Land Survey at Missouri Department of Natural Resources, we calculated a sinkhole-potential surface (Fig. 7B) based on the weighted density of sinkhole records. The weights are based on the reliability of the sinkhole records, considering those created from data sources of higher resolutions and/or have been verified by field visits more reliable and given higher weights. A sinkhole-potential measure was then calculated based on combined sinkhole-potential values within a 400-meter buffer of the sink.

Understanding that groundwater withdraw contributes to sinkhole risk, we calculated a well yield (gallons per minute) surface using the well yield (gallons per minute) information in the wells data (Fig. 7C). A sinkhole risk measure was then derived based on the total well yield within a 400 -meter buffer of the sink.

\section{(A) Neighborhood sink density} (sinks / square kilometer)

$$
\begin{aligned}
& \text { - } 6-30 \\
& -31-40 \\
& -41-50 \\
& \text { - } 51-71
\end{aligned}
$$

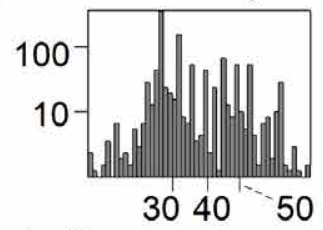

\section{0-m sink buffer}

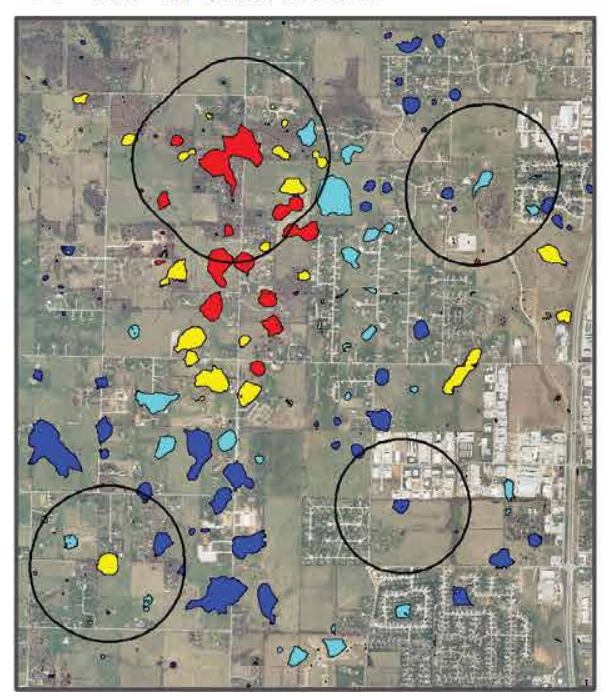

(B) Sinkhole potential

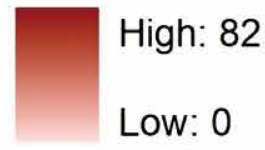

- Verified sinkhole records

- Not verified sinkhole records

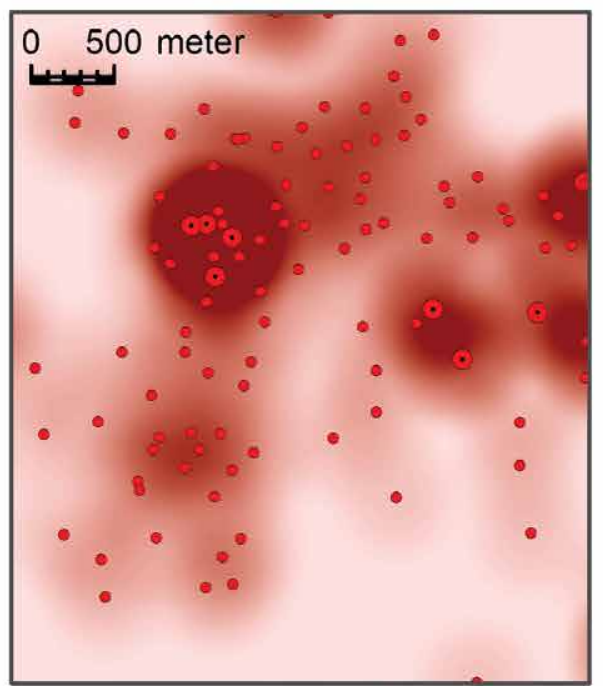

(C) Well yield (gallons / minute)

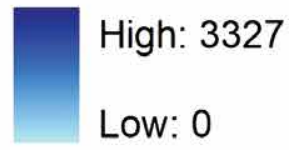

\section{$\triangle$ Wells}

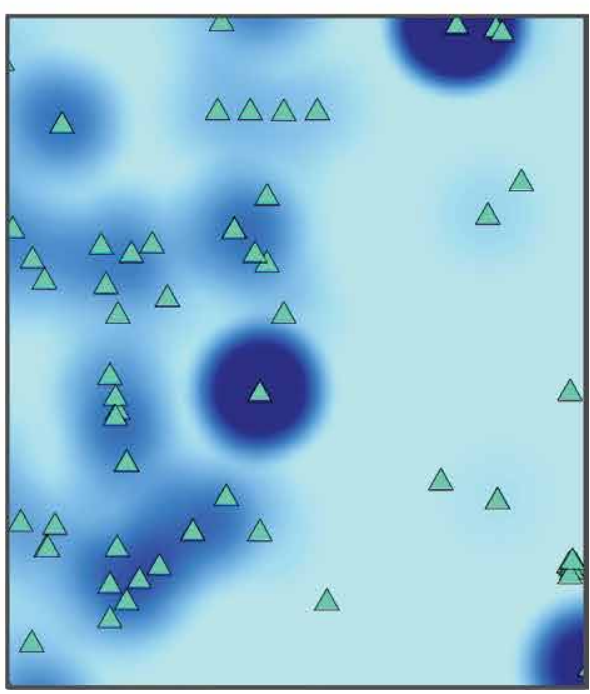

Figure 7. Ranking of sinks based on 400-m-buffer sink density (A), interpolated sinkhole potential surface based on existing sinkhole records $(B)$, and interpolated well-yield surface from wells data $(C)$. 
(A) Bedrock depth (meter)

High: 42.7

Low: 2.7

Sink polygons
(B) Weighted susceptibility score

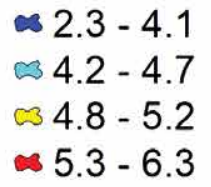

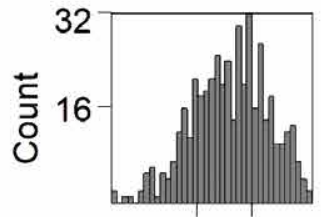

$4.0 \quad 5.0$
(C) Sinkhole susceptibility

High: 6.25

Low: 2.39

œ Sink polygons
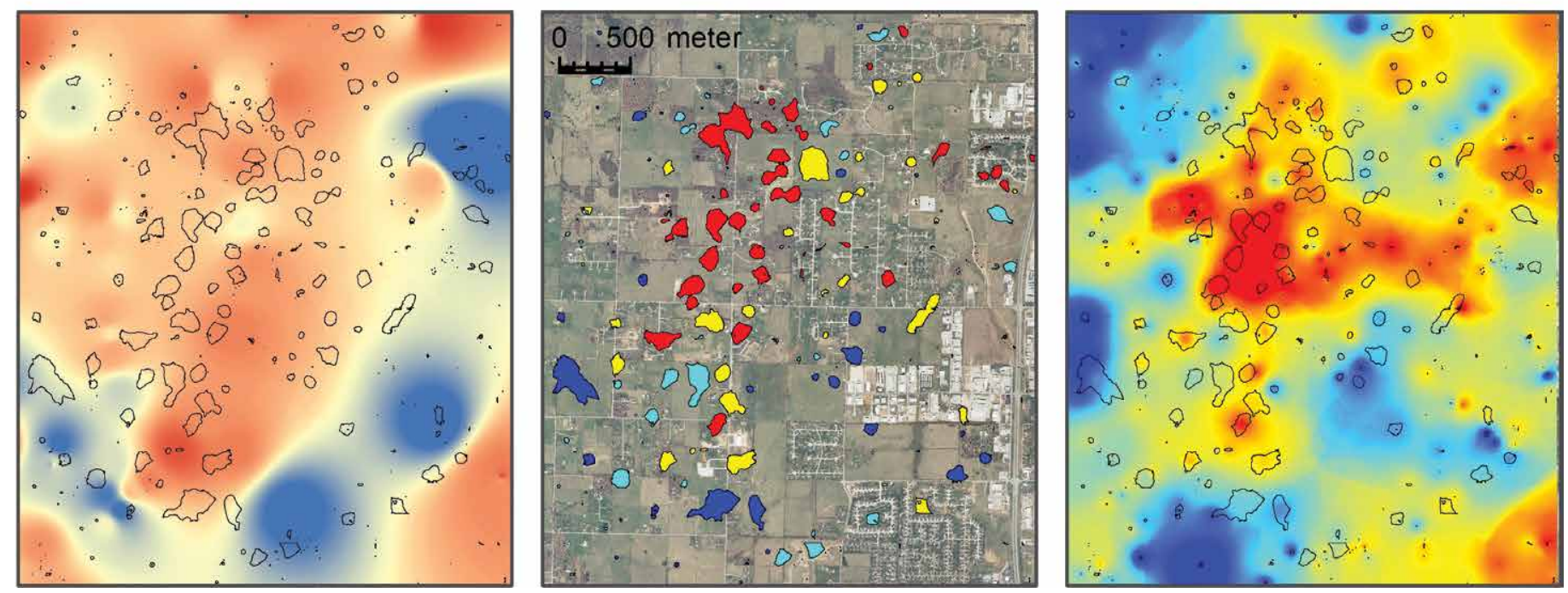

Figure 8. Interpolated bedrock depth surface based on wells data (A), ranking of sinks based on the weighted susceptibility score from all attributes (B), and an interpolated surface of sinkhole susceptibility (C).

Considering that the depth to bedrock has an effect on the probability of sinkhole collapse, we estimated the bedrock depth (Fig. 8A) based on descriptions and depth information of formations in the wells data. A bedrock depth surface was then interpolated from the bedrock depth data. Further, a sinkhole risk measure was calculated based on the maximum bedrock depth within a 100-meter buffer of the sink.

\section{Combining all Sinks Attributes for Sinkhole Susceptibility Assessment}

Lastly, all sink attributes were combined for susceptibility assessment. Each ratio variable of sink attributes was classified into nine ranges with each range of 50 sink records. Classifying sink attributes by broad range allows minimizing the inherent uncertainty of sink attributes in denoting sinkhole susceptibility. Sinks in each range were assigned a corresponding susceptibility score from 1 to 9 , with 9 being the most potentially dangerous or of highest priority for sinkhole management (Table 3).

For categorical variables, including the seasonal water condition and land use types, a score between 2 and 8 was assigned based on the risk implication of the attribute. We did not use the score range of 1 to 9 as others have done in order to minimize the uncertainty and potential error in quantifying categorical variables. Specifically, using a smaller interval with a larger minimum and a smaller maximum will make categorical variables less influential to the overall susceptibility scores combined from all variables.

To identify high-priority sinkholes for sinkhole prevention and mitigation efforts, we combined susceptibility scores from each attribute through a weighting approach. In principle, the weight should be determined by how the attribute denotes the probability of sinkhole-causing property damage and human injury. Practically, the weight is decided based on the analysis objectives as well as the assessor's opinions of what are considered important. In this study, higher weights are assigned to the attributes that we considered as important risk indicators, while lower weights are given to attributes that we considered less reliable due to spatial data precision (Table 4). Specifically, the following five criteria are utilized in assigning weights:

1. Unless meeting the following criteria, all attributes are taken as moderate risk indicators and are assigned a neutral weight of 1 ;

2. If the attribute is commonly used as sinkhole susceptibility indicator with solid theoretical support, it is given a weight of 2 ;

3. The attribute of land use is given a weight of 4 , considering that sinkhole management priority is usually given to the developed/developing urban areas, which are mainly commercial and residential land use. 
Table 3. Classification of sink attributes and the value ranges in each class.

\begin{tabular}{|c|c|c|}
\hline Attributes & $\begin{array}{c}\text { Classes } \\
\text { (Susceptibility } \\
\text { Scores) }\end{array}$ & Value Ranges \\
\hline Size (square meters) & $\begin{array}{l}9 \\
8 \\
7 \\
6 \\
5 \\
4 \\
3 \\
2 \\
1\end{array}$ & $\begin{array}{c}5342-59648 \\
858-5341 \\
177-857 \\
45-176 \\
22-44 \\
13-21 \\
8-12 \\
6-7 \\
3-5\end{array}$ \\
\hline Shape complexity & $\begin{array}{l}9 \\
8 \\
7 \\
6 \\
5 \\
4 \\
3 \\
2 \\
1\end{array}$ & $\begin{array}{l}5.73-8.42 \\
5.07-5.72 \\
4.77-5.06 \\
4.44-4.76 \\
4.25-4.43 \\
4.10-4.24 \\
3.98-4.09 \\
3.86-3.97 \\
3.64-3.85\end{array}$ \\
\hline Depth to diameter ratio & $\begin{array}{l}9 \\
8 \\
7 \\
6 \\
5 \\
4 \\
3 \\
2 \\
1\end{array}$ & $\begin{array}{l}0.53-0.78 \\
0.44-0.52 \\
0.37-0.43 \\
0.28-0.36 \\
0.20-0.27 \\
0.14-0.19 \\
0.10-0.13 \\
0.07-0.09 \\
0.02-0.06\end{array}$ \\
\hline Terrain ruggedness & $\begin{array}{l}9 \\
8 \\
7 \\
6 \\
5 \\
4 \\
3 \\
2 \\
1\end{array}$ & $\begin{array}{l}0.167-1.585 \\
0.125-0.166 \\
0.105-0.124 \\
0.084-0.104 \\
0.072-0.083 \\
0.060-0.071 \\
0.049-0.059 \\
0.037-0.048 \\
0.008-0.036\end{array}$ \\
\hline Impervious surface (\%) & $\begin{array}{l}9 \\
8 \\
7 \\
6 \\
5 \\
4 \\
3 \\
2 \\
1\end{array}$ & $\begin{array}{c}16.5-56.9 \\
11.6-16.4 \\
8.5-11.5 \\
6.3-8.4 \\
4.7-6.2 \\
3.4-4.6 \\
1.7-3.3 \\
0.6-1.6 \\
0.0-0.5\end{array}$ \\
\hline NDVI & $\begin{array}{l}9 \\
8 \\
7 \\
6 \\
5 \\
4 \\
3 \\
2 \\
1\end{array}$ & $\begin{array}{c}-0.30--0.04 \\
-0.03-0.06 \\
0.07-0.19 \\
0.20-0.27 \\
0.28-0.33 \\
0.34-0.39 \\
0.40-0.43 \\
0.44-0.48 \\
0.49-0.61\end{array}$ \\
\hline Seasonal water condition & $\begin{array}{l}7 \\
5 \\
3\end{array}$ & $\begin{array}{l}\text { Constant dry } \\
\text { Intermittent } \\
\text { Constant wet }\end{array}$ \\
\hline
\end{tabular}

4. The attribute of seasonal water condition is given a weight of 0.5 , considering that the susceptibility score for a corresponding category is relatively generalized and may be unreliable;

5. The attribute of vegetation growth index is given a weight of 0.5 , considering that vegetation would not have much stabilizing effects when surficial materials above bedrock are thick, and a sinkhole collapse will occur at some time regardless of the vegetation cover.

Using the defined weight for each sink attribute, we calculated the overall weighted susceptibility scores for sinks and ranked them by four ranges with similar number of sinks in each range (Fig. 8B). As the final, combined susceptibility scores are interpreted in broad ranges, it is reasonable to mark sinks in higher ranks with higher priority for further investigation or prevention management than sinks in lower ranks. It appears that high-susceptibility sinks cluster in the central part of the study area. Understanding that many small sinks cannot be observed on maps, we interpolated a sinkhole susceptibility surface from the susceptibility scores based on the centroids of sink polygons (Fig. 8C). The interpolated susceptibility surface highlights the red risk zones of high sinkhole susceptibility. Those red areas are considered having high priority for further field-based geophysical investigation, as well as for conducting sinkhole prevention and mitigation activities. Some sinkhole management strategies may include:

- Minimizing new land development and construction activities in the area;

- Regularly monitoring the ground conditions for sinks in the area;

- Educating/notifying land owners of the potential sinkholes in their properties.

\section{Discussion}

This study presents a computerized approach for sinkhole susceptibility assessment based on sink attributes that can be efficiently derived from digital data of elevation, aerial photos, parcel land use/zoning, and census demographics. The advantage of this approach is that emergency managers and planners can use it to quickly identify high-priority sinkholes. The disadvantage of the approach is that it could not confirm the existence of sinkholes, because the assessment is based on sinkhole risk indicators and human vulnerability considerations. The actual geological activities underground can only be verified through geophysical investigation using ground penetrating radar (GPR). Nevertheless, from another point of view, results from this 
Table 3. (Continued).

\begin{tabular}{|c|c|c|}
\hline Attributes & $\begin{array}{c}\text { Classes } \\
\text { (Susceptibility } \\
\text { Scores) }\end{array}$ & Value Ranges \\
\hline Land use & $\begin{array}{l}8 \\
6 \\
4 \\
2\end{array}$ & $\begin{array}{c}\text { Commercial } \\
\text { Suburban residential } \\
\text { Rural residential } \\
\text { Agricultural/ } \\
\text { Manufacturing }\end{array}$ \\
\hline $\begin{array}{c}\text { Population density } \\
\text { (persons/square kilometer) }\end{array}$ & $\begin{array}{l}9 \\
8 \\
7 \\
6 \\
5 \\
4 \\
3 \\
2 \\
1\end{array}$ & $\begin{array}{c}451-1660 \\
298-450 \\
222-297 \\
161-221 \\
140-160 \\
116-139 \\
78-115 \\
49-77 \\
0-48\end{array}$ \\
\hline $\begin{array}{l}\text { Hydrological flow } \\
\text { accumulation } \\
\text { (square meters) }\end{array}$ & $\begin{array}{l}9 \\
8 \\
7 \\
6 \\
5 \\
4 \\
3 \\
2 \\
1\end{array}$ & $\begin{array}{c}10977-89841 \\
1245-10976 \\
468-1244 \\
226-467 \\
89-225 \\
29-88 \\
11-28 \\
5-10 \\
0-4\end{array}$ \\
\hline $\begin{array}{c}\text { Sink density } \\
\text { (sinks/square kilometer) }\end{array}$ & $\begin{array}{l}9 \\
8 \\
7 \\
6 \\
5 \\
4 \\
3 \\
2 \\
1\end{array}$ & $\begin{array}{c}62-71 \\
54-61 \\
49-53 \\
44-48 \\
37-43 \\
32-36 \\
28-31 \\
23-27 \\
6-22\end{array}$ \\
\hline Sinkhole potential & $\begin{array}{l}9 \\
8 \\
7 \\
6 \\
5 \\
4 \\
3 \\
2 \\
1 \\
0\end{array}$ & $\begin{array}{c}21-33 \\
12-20 \\
9-11 \\
8 \\
6-7 \\
5 \\
4 \\
2-3 \\
1 \\
0\end{array}$ \\
\hline Well yield & $\begin{array}{l}9 \\
8 \\
7 \\
6 \\
5 \\
4 \\
3 \\
2 \\
1 \\
0\end{array}$ & $\begin{array}{c}581-960 \\
376-580 \\
251-375 \\
231-250 \\
181-230 \\
141-180 \\
98-140 \\
36-97 \\
1-35 \\
0\end{array}$ \\
\hline Bedrock depth & $\begin{array}{l}9 \\
8 \\
7 \\
6 \\
5 \\
4 \\
3 \\
2 \\
1\end{array}$ & $\begin{array}{r}6.6-10.4 \\
10.5-12.0 \\
12.1-12.7 \\
12.8-14.1 \\
14.2-16.0 \\
16.1-18.3 \\
18.4-21.0 \\
21.1-29.3 \\
29.4-42.7\end{array}$ \\
\hline
\end{tabular}

computerized approach can be used as an initial framework to prioritize limited resources for sinkhole investigation and mitigation (Zumpano et al., 2019).

This study assessed sinkhole susceptibility based on fourteen sink attributes. The advantage of the proposed attributes is that many of them are intended to be suitable for a hilly, vegetated karst terrain and are, therefore, applicable to areas of similar landscape. Furthermore, the proposed attributes can be conveniently derived from common GIS and imagery data without time-consuming data collection in the field.

There are two potential disadvantages of using the proposed sink attributes for susceptibility assessment. The first is the inherent errors in data source and in computational analysis. Particularly, the resolutions of the DTMs and aerial photos, and the rigor of the procedures used to derive the attributes affect the accuracy of all the attributes. The second disadvantage of using these attributes for susceptibility assessment is the inherent uncertainty in the relevancy of the attributes denoting sinkhole risk, since the relationships between attribute and sinkhole incidence are hard to quantitatively define.

As this study combined all criteria for sinkhole susceptibility assessment by mathematically adding the susceptibility scores, it is worth noting that different sinkhole variables may not be comparable and, therefore, their respective susceptibility (scores) may not be accumulated directly. Nevertheless, multiple-criteria decision analysis (MCDA) requests certain conclusions be drawn to aid decision making. Accordingly, we combined susceptibility scores and classified the combined scores in four broad ranges to minimize the inherent errors while allowing for ranking and prioritizing sinkholes.

As the attribute weights are assigned based on our perception and understanding of what attributes are considered important and/or reliable, other studies using the same variables may adjust the weights based on their analysis needs/objectives. Furthermore, future research may model how the attributes collectively relate to quantified sinkhole incidence (e.g., using linear regression analysis). Through the calibration of model parameters, the attribute weights for combing susceptibility scores may be defined more objectively and with a higher precision.

Specific rock materials play a significant role in how sinkholes are formed as well as the probability of sinkhole incidence. For example, in our karst study area dominated by carbonate limestone, if the rock materials contain impure 
Table 4. The weights assigned to each sink attribute for combining them for sinkhole susceptibility assessment.

\begin{tabular}{lcl}
\multicolumn{1}{c}{ Attributes } & Weights & Considerations for Assigning Weights \\
\hline - Size & 1 & - Reasonable susceptibility indicator \\
- Shape complexity & 1 & - Reasonable susceptibility indicator \\
- Depth to diameter ratio & 2 & Solid theoretical support \\
- Terrain ruggedness & 1 & Reasonable susceptibility indicator \\
& & \\
- Impervious surface \% & 1 & - Reasonable susceptibility indicator \\
- NDVI & 0.5 & - Vegetation matters little when soil is thick \\
- Seasonal water condition & 0.5 & \\
& & \\
- Land use & & - Strongorical variable with inherent uncertainty \\
- Population density & 4 & - Solid theoretical support \\
- Hydrological flow accumulation & 2 & - Solid theoretical support \\
- Sink density & 2 & - Solid theoretical support \\
- Sinkhole potential & 2 & - Reasonable susceptibility indicator \\
- Well yield & 2 & Reasonable susceptibility indicator \\
- Bedrock depth & 1 &
\end{tabular}

carbonate rocks or interbedded insoluble lithology in limestone sequences, the dissolution process would operate at relatively slow rates, which allows sagging and suffusion sinkholes to be more common than otherwise. In contrast, if the carbonate rocks contain pure minerals of calcite and dolomite, the rocks will be considerably soluble to allow voids and cracks to form; and collapse sinkholes will have a higher probability to occur than otherwise.

Past researchers have shown that sinkholes are likely to occur along geological faults (Florea 2005; Closson and Karaki 2009). For the Ozark karst region, the overall direction of faults is from northwest to southeast. Nevertheless, we did not consider the location of fault as a criterion for susceptibility assessment because our study area is relatively small without major faults. For studies covering large area with many faults, the location and direction of existing faults may be regarded as an important factor for assessing sinkhole susceptibility.

There are many man-made sinks in our study area and we only filter out those with considerably elongated or jagged shapes through a shape complexity index. Understand that some apparent man-made sinks may be initially created by natural, geological mechanism but later reshaped by human activities. For example, in developed urban areas, humans may build detention ponds and roadside swales upon existing land depressions. In undeveloped rural areas, naturally formed sinks or lakes may be disturbed by agriculture or farm activities.

The geologic process and formation of sinkholes may be induced or expedited by human activities, such as mining, deforestation, over irrigation, groundwater pumping, broken sewer lines or water mains, inappropriately buried organic debris, and improperly compacted construction soil after excavation (Kochanov, 1999; Gutiérrez et al. 2008, 2014). Due to this complex human-landscape interaction, detailed geophysical investigation is needed to verify whether the appeared man-made sinks are solely created by human activities or have geological origins with potential sinkhole hazard.

When assessing sinkhole susceptibility based on impervious surface percentage, we classified the impervious surface land cover from digital aerial photos using the traditional, most commonly used, maximum likelihood classification algorithm. A close examination of the classified results on aerial photos indicates that some barren lands were misclassified as impervious surface, while some road surfaces were not classified as they should. More advanced classification algorithms such as neural network and decision tree, or more sophisticated object-based image software such as e-Cognition or Feature Analyst, may help improve the classification results. Nevertheless, more advanced image classification approaches often have more algorithm/software parameters for users to consider. The determination of optimal parameters often requires a calibration process consisting of trial-and-error experiments that may be time consuming (Wu et al., 2009).

To derive the seasonal water condition for sinks, we used a straightforward change detection method in remote sensing in which a pair of winter and summer aerial photos are classified individually and then compared. Future sinkhole analysis may test other change detection techniques that may be more efficient and/or accurate. For example, algebra-based approaches like image differencing, image regression, and change vector analysis may streamline the analysis, though initial radiometric normalization between the two photos would be required.

This study examines the surface water conditions of sinks in order to estimate potential sinkhole risk. The advantage of this approach is that it is convenient to detect the existence of surface water from aerial photos. It is worth noting that groundwater supply also plays a role in the formation and stability of sinkholes. Specifically, the lowering of the groundwater table during the dry season or from excessive groundwater pumping may facilitate the formation of cover-collapse sinkholes due to the effect of the drawdown of the piezometric surface in the karst aquifer (Tharp, 2002). 


\section{Conclusions}

This study develops robust methodology for computerized sinkhole susceptibility assessment based on common GIS and imagery data. The methodology of extracting sinks and assessing potential sinkhole risk by sink attributes can be efficiently applied to other karst areas, particularly areas in a hilly and vegetated landscape.

The selected sinkhole attributes for susceptibility assessment can be conveniently derived with available GIS tools, specifically tools in the widely-accessible ArcGIS software. For the fourteen sinkhole attributes used in this study, three of their uses are deemed innovative, considering that they have not been used in past studies to assess sinkhole susceptibility. These three sinkhole attributes include:

- The terrain ruggedness index and the maximum hydrological flow accumulation, which can be derived from bare-ground DTMs;

- The Normalized Difference Vegetation Index (NDVI), which can be derived from 4-band digital photos.

The proposed computerized susceptibility ranking approach can be effectively used as an initial sinkhole analysis to determine where more detailed site investigation and data collection are warranted. The findings of the high-susceptibility sinkholes as well as the corresponding 'risk zone' in the Nixa karst area can be used to support decision making in prioritizing limited emergency planning and management resources. For example, field-based investigation using GPR can be further conducted for those high-priority sinks to examine their underground geophysical structures and the probability of further sinkhole activities. If high probability of future sinkhole incidents is confirmed, the landowner should build a barrier at a safe distance to prevent access to the sinkhole. Further, if the confirmed high-risk sinkholes are located in a populated neighborhood, it may be necessary to properly fill and physically stabilize the void to mediate the potential of future collapse.

\section{References}

Al-Halbouni, D., Holohan, E.P., Saberi, L., Alrshdan, H., Sawarieh, A., Closson, D., Walter, T.R., and Dahm, T., 2017, Sinkholes, subsidence and subrosion on the eastern shore of the Dead Sea as revealed by a close-range photogrammetric survey: Geomorphology, v. 285 , p. $305-324$. .https://doi.org/10.1016/j.geomorph.2017.02.006

Angel, J.C., Nelson, D.O., and Panno, S.V., 2004, Comparison of a new GIS-based technique and a manual method for determining sinkhole density: An example from Illinois' sinkhole plain: Journal of Cave and Karst Studies, v. 66, no. 1, p. 9-17.

Aplin, P., Atkinson, P.M., and Curran, P.J., 1999, Fine spatial resolution simulated satellite sensor imagery for land cover mapping in the United Kingdom: Remote Sensing of Environment, v. 68, no. 3, p. 206-216. https://doi.org/10.1016/S0034-4257(98)00112-6.

Applegate, P., 2003, Detection of sinkholes developed on shaley Ordovician limestones, Hamilton County, Ohio, using digital topographic data: Dependence of topographic expression of sinkholes on scale, contour interval, and slope: Journal of cave and karst studies, v. 65 , no. 2 , p. 126-129.

Ascione, A., Cinque, A., Miccadei, E., Villani, F., and Berti, C., 2008, The Plio-Quaternary uplift of the Apennine chain: New data from the analysis of topography and river valleys in Central Italy: Geomorphology, v. 102, no. 1, p. 105-118. https://doi.org/10.1016/j.geomorph.2007.07.022.

Atash, F., 1994, Redesigning suburbia for walking and transit: Emerging concepts: Journal of Urban Planning and Development, v. 120, no. 1, p. 48-57. https://doi.org/10.1061/(ASCE)0733-9488(1994)120:1(48).

Atzori, S., Baer, G., Antonioli, A., and Salvi, S., 2015, InSAR-based modeling and analysis of sinkholes along the Dead Sea coastline: Geophysical Research Letters, v. 42, no. 20, p. 8383-8390. https://doi.org/10.1002/2015GL066053.

Barredo, J., Benavides, A., Hervas, J., and van Westen, C.J., 2000, Comparing heuristic landslide hazard assessment techniques using GIS in the Tirajana basin, Gran Canaria Island, Spain: International Journal of Applied Earth Observation and Geoinformation, v. 2, no. 1, p. 9-23. https://doi.org/10.1016/S0303-2434(00)85022-9.

Basso, A., Bruno, E., Parise, M., and Pepe, M., 2013, Morphometric analysis of sinkholes in a karst coastal area of southern Apulia (Italy): Environmental earth sciences, v. 70, no. 6, p. 2545-2559. https://doi.org/10.1007/s12665-013-2297-z.

Brinkmann, R., Parise, M., and Dye, D., 2008, Sinkhole distribution in a rapidly developing urban environment: Hillsborough County, Tampa Bay area, Florida: Engineering Geology, v. 99, no. 3-4, p. 169-184. https://doi.org/10.1016/j.enggeo.2007.11.020.

BGS (British Geological Survey), 2017, Dolines and sinkholes, http://www.bgs.ac.uk/mendips/caveskarst/Karst_3.htm [accessed August 18, 2019].

Bullock, P.J., and Dillman, A., 2003, Sinkhole detection in Florida Using GPR and CPT, http://citeseerx.ist.psu.edu/viewdoc/download?doi=10.1.1.540.5058\&rep=rep1\&type=pdf [accessed August 18, 2019].

Castellanos Abella, E.A., and Van Westen, C.J., 2007, Generation of a landslide risk index map for Cuba using spatial multi-criteria evaluation: Landslides, v. 4, no. 4, p. 311-325. https://doi.org/10.1007/s10346-007-0087-y.

Castellanos Abella, E.A., and Van Westen, C.J., 2008, Qualitative landslide susceptibility assessment by multicriteria analysis: a case study from San Antonio del Sur, Guantánamo, Cuba: Geomorphology, v. 94, no. 3-4, p. 453-466. https://doi.org/10.1016/j.geomorph.2006.10.038.

Chalkias, C., Ferentinou, M., and Polykretis, C., 2014, GIS supported landslide susceptibility modeling at regional scale: An expert-based fuzzy weighting method: ISPRS International Journal of Geo-Information, v. 3, no. 2, p. 523-539. https://doi.org/10.3390/ijgi3020523.

Chalkias, C., Polykretis, C., Ferentinou, M., and Karymbalis, E., 2016, Integrating expert knowledge with statistical analysis for landslide susceptibility assessment at regional scale: Geosciences, v. 6, no. 1, p. 14. https://doi.org/10.3390/geosciences6010014.

Ciotoli, G., Di Loreto, E., Finoia, M.G., Liperi, L., Meloni, F., Nisio, S., and Sericola, A., 2016, Sinkhole susceptibility, Lazio Region, central Italy: Journal of Maps, v. 12, no. 2, p. 287-294. https://doi.org/10.1080/17445647.2015.1014939.

Closson, D., and Karaki, N.A., 2009, Salt karst and tectonics: Sinkholes development along tension cracks between parallel strike-slip faults, Dead Sea, Jordan: Earth Surface Processes and Landforms, v. 34, no. 10, p. 1408-1421. https://doi.org/10.1002/esp.1829.

Dai, F.C., Lee, C.F., and Ngai, Y.Y., 2002, Landslide risk assessment and management: an overview: Engineering Geology, v. 64, no. 1 , p. $65-87$. https://doi.org/10.1016/S0013-7952(01)00093-X.

De León, V., and Carlos, J., 2006, Vulnerability: a conceptional and methodological review, http://collections.unu.edu/eserv/unu:1871/pdf3904. 
pdf [accessed August 18, 2019].

Del Prete, S., lovine, G., Parise, M., and Santo, A., 2010, Origin and distribution of different types of sinkholes in the plain areas of Southern Italy: Geodinamica Acta, v. 23, no. 1-3, p. 113-127. https://doi.org/10.3166/ga.23.113-127.

Denizman, C.A.N., 2003, Morphometric and spatial distribution parameters of karstic depressions, Lower Suwannee River Basin, Florida: Journal of Cave and Karst Studies, v. 65, no. 1, p. 29-35.

Doctor, D.H., and Young, J.A., 2013, An evaluation of automated GIS tools for delineating karst sinkholes and closed depressions from 1-meter LIDAR-derived digital elevation data, https://scholarcommons.usf.edu/cgi/viewcontent.cgi?article=1156\&context=sinkhole_2013 [accessed August 18, 2019]. https://doi.org/10.5038/9780979542275.1156.

ESRI, 2016, NDVI Function, http://desktop.arcgis.com/en/arcmap/10.4/manage-data/raster-and-images/ndvi-function.htm [accessed August 18, 2019].

Feizizadeh, B., and Blaschke, T., 2014, An uncertainty and sensitivity analysis approach for GIS-based multicriteria landslide susceptibility mapping: International Journal of Geographical Information Science, v. 28, no. 3, p. 610-638. https://doi.org/10.1080/13658816.2013.869821.

Festa, V., Fiore, A., Parise, M., and Siniscalchi, A., 2012, Sinkhole evolution in the Apulian karst of southern Italy: a case study, with some considerations on sinkhole hazards: Journal of Cave and Karst Studies, v. 74, no. 2, p. 137-147. https://doi.org/10.4311/2011JCKS0211.

Florea, Lee J. 2005, Using State-wide GIS data to identify the coincidence between sinkholes and geologic structure. Journal of Cave and Karst Studies, v. 67 , no. 2, p. $120-124$

Galve, J.P., Bonachea, J., Remondo, J., Gutiérrez, F., Guerrero, J., Lucha, P., Cendrero, A., Gutiérrez, M., and Sánchez, J.A., 2008, Development and validation of sinkhole susceptibility models in mantled karst settings: A case study from the Ebro valley evaporite karst (NE Spain): Engineering Geology, v. 99, no. 3-4, p. 185-197. https://doi.org/10.1016/j.enggeo.2007.11.011.

Galve, J.P., Gutiérrez, F., Lucha, P., Guerrero, J., Bonachea, J., Remondo, J., and Cendrero, A., 2009a, Probabilistic sinkhole modelling for hazard assessment: Earth Surface Processes and Landforms, v. 34, no. 3, p. 437-452. https://doi.org/10.1002/esp.1753.

Galve, J.P., Gutiérrez, F., Cendrero, A., Remondo, J., Bonachea, J., Guerrero, J., and Lucha, P., 2009b, Predicting sinkholes by means of probabilistic models: Quarterly Journal of Engineering Geology and Hydrogeology, v. 42, no. 2, p. 139-144. https://doi.org/10.1144/1470-9236/08039.

Galve, J.P., Gutiérrez, F., Remondo, J., Bonachea, J., Lucha, P., and Cendrero, A., 2009c, Evaluating and comparing methods of sinkhole susceptibility mapping in the Ebro Valley evaporite karst (NE Spain): Geomorphology, v. 111, no. 3-4, p. 160-172. https://doi.org/10.1016/j. geomorph.2009.04.017.

Geneletti, D., and Gorte, B.G.H., 2003, A method for object-oriented land cover classification combining Landsat TM data and aerial photographs: International Journal of Remote Sensing, v. 24, no. 6, p. 1273-1286. https://doi.org/10.1080/01431160210144499.

Gouzie, D., and Pendergrass, G., 2009, Investigation and remediation of the 2006 Nixa, Missouri, collapse sinkhole, Environmental \& Engineering Geoscience, v. 15, no. 1, p. 13-27. https://doi.org/10.2113/gseegeosci.15.1.13.

Gutierrez, F., Cooper, A.H., and Johnson, K.S., 2008, Identification, prediction, and mitigation of sinkhole hazards in evaporite karst areas: Environmental Geology, v. 53, no. 5, p. 1007-1022. https://doi.org/10.1007/s00254-007-0728-4.

Gutiérrez, F., Parise, M., De Waele, J., and Jourde, H., 2014, A review on natural and human-induced geohazards and impacts in karst: Earth-Science Reviews, v. 138, p. 61-88. https://doi.org/10.1016/j.earscirev.2014.08.002.

Handfelt, L.D., and Attwooll, W.J., 1988, Exploration of karst conditions in central Florida, in Sitar, N., ed., Geotechnical Aspects of Karst Terrains: Exploration, Foundation Design and Performance, and Remedial Measures: ASCE, p. 40-52.

Intrieri, E., Gigli, G., Nocentini, M., Lombardi, L., Mugnai, F., Fidolini, F., and Casagli, N., 2015, Sinkhole monitoring and early warning: An experimental and successful GB-InSAR application: Geomorphology, v. 241, p. 304-314. https://doi.org/10.1016/j.geomorph.2015.04.018.

Jensen, J.R., 2005, Introductory digital image processing: A remote sensing perspective, Upper Saddle River, N.J.: Prentice Hall.

Kaufmann, J.E., 2007, Catastrophic Sinkhole Collapse in Missouri, http://pubs.usgs.gov/fs/2007/3060 [accessed August 18, 2019].

Kaufmann, G., 2014, Geophysical mapping of solution and collapse sinkholes: Journal of Applied Geophysics, v. 111, p. 271-288. https://doi. org/10.1016/j.jappgeo.2014.10.011.

Kaufmann, G., and Romanov, D., 2016, Structure and evolution of collapse sinkholes: Combined interpretation from physico-chemical modelling and geophysical field work: Journal of Hydrology, v. 540, p. 688-698. https://doi.org/10.1016/j.jhydrol.2016.06.050.

Kochanov, W.E., 1999, Sinkholes in Pennsylvania: Pennsylvania Geological Survey, 4th ser., Educational Series, v. 11, p. 33.

Komac, M., 2006, A landslide susceptibility model using the analytical hierarchy process method and multivariate statistics in perialpine Slovenia: Geomorphology, v. 74, no. 1-4, p. 17-28. https://doi.org/10.1016/j.geomorph.2005.07.005.

Krawczyk, C.M., Polom, U., Trabs, S., and Dahm, T., 2012, Sinkholes in the city of Hamburg-new urban shear-wave reflection seismic system enables high-resolution imaging of subrosion structures: Journal of Applied Geophysics, v. 78, p. 133-143. https://doi.org/10.1016/j.jappgeo.2011.02.003.

Krizek, K.J., 2003, Neighborhood services, trip purpose, and tour-based travel: Transportation, v. 30, no. 4, p. 387-410. https://doi. org/10.1023/A:1024768007730

Lamelas, M.T., Marinoni, O., Hoppe, A., and De La Riva, J., 2008, Doline probability map using logistic regression and GIS technology in the central Ebro Basin (Spain): Environmental Geology, v. 54, no. 5, p. 963-977. https://doi.org/10.1007/s00254-007-0895-3.

Lee, E.M., and Jones, D.K., 2004, Landslide Risk Assessment. London: Thomas Telford.

Margiotta, S., Negri, S., Parise, M., and Valloni, R., 2012, Mapping the susceptibility to sinkholes in coastal areas, based on stratigraphy, geomorphology and geophysics: Natural Hazards, v. 62, no. 2, p. 657-676. https://doi.org/10.1007/s11069-012-0100-1.

McCormack, G.R., Giles-Corti, B., and Bulsara, M., 2008, The relationship between destination proximity, destination mix and physical activity behaviors: Preventive Medicine, v. 46, no. 1, p. 33-40. https://doi.org/10.1016/j.ypmed.2007.01.013.

Molina, S., Lang, D.H., and Lindholm, C.D., 2010, SELENA-An open-source tool for seismic risk and loss assessment using a logic tree computation procedure: Computers \& Geosciences, v. 36, no. 3, p. 257-269. https://doi.org/10.1016/j.cageo.2009.07.006.

Moser, D., Zechmeister, H.G., Plutzar, C., Sauberer, N., Wrbka, T., and Grabherr, G., 2002, Landscape patch shape complexity as an effective measure for plant species richness in rural landscapes: Landscape Ecology, v. 17, no. 7, p. 657-669. https://doi. org/10.1023/A:1021513729205.

Nsengiyumva, J.B., Luo, G., Nahayo, L., Huang, X., and Cai, P., 2018, Landslide susceptibility assessment using spatial multi-criteria evaluation model in Rwanda: International Journal of Environmental Research and Public Health, v. 15, no. 2, p. 243. https://doi.org/10.3390/ ijerph15020243.

Parise, M., 2010, Hazards in karst, in Sustainability of the Karst Eenvironment: Dinaric Karst and Other Karst Regions, Bonacci, O., ed., IHP-VII UNESCO, Series on Groundwater No. 2, p. 155-162. 
Parise, M., 2015a, A procedure for evaluating the susceptibility to natural and anthropogenic sinkholes: Georisk, v. 9, no. 4, p. 272-285. https:// doi.org/10.1080/17499518.2015.1045002.

Parise, M., 2015b, Karst geo-hazards: Causal factors and management issues: Acta Carsologica, v. 44, no. 3, p. 401. https://doi.org/10.3986/ ac.v44i3.1891.

Parise, M., Ravbar, N., Živanović, V., Mikszewski, A., Kresic, N., Mádl-Szőnyi, J., and Kukurić, N., 2015, Hazards in karst and managing water resources quality, in Karst Aquifers-Characterization and Engineering, Springer, Cham, p. 601-687. https://doi.org/10.1007/978-3-31912850-4 17.

Peduzzi, P., Dao, H., Herold, C., and Mouton, F., 2009, Assessing global exposure and vulnerability towards natural hazards: the Disaster Risk Index: Natural Hazards and Earth System Sciences, v. 9, no. 4, p. 1149-1159. https://doi.org/10.5194/nhess-9-1149-2009.

Peduzzi, P., and Herold, H.D.C., 2005, Mapping disastrous natural hazards using global datasets: Natural Hazards, v. 35, no. 2, p. $265-289$. https://doi.org/10.1007/s11069-004-5703-8.

Porter, J., and Thomson, K.C., 1975, Geology, geomorphology and karst development in the Nixa karst area, Southwestern Missouri: Geosciences Series 2, Department of Geography and Geology, Southwest Missouri State University.

Qiu, X. and Wu, S., 2017, A Knowledge-based computerized approach to the development of a sinkhole database: The Professional Geographer, v. 69, no. 2, p. 239-250. https://doi.org/10.1080/00330124.2016.1229622.

Reese, S.O., and Kochanov, W.E., 2003, Digital karst density layer and compilation of mapped karst features in Pennsylvania, U.S. Geological Survey Open-File Report, p. 3-471.

Sarker, J.K., Ansary, M.A., Rahman, M.S., and Safiullah, A.M.M., 2010, Seismic hazard assessment for Mymensingh, Bangladesh: Environmental Earth Sciences, v. 60, no. 3, p. 643-653. https://doi.org/10.1007/s12665-009-0204-4.

Schmidt, J., Matcham, I., Reese, S., King, A., Bell, R., Henderson, R., Smart, G., Cousins, J., Smith, W., and Heron, D., 2011, Quantitative multirisk analysis for natural hazards: A framework for multi-risk modelling: Natural Hazards, v. 58, no. 3, p. 1169-1192. https://doi.org/10.1007/ s11069-011-9721-z.

Seale, L.D., Florea, L.J., Vacher, H.L., and Brinkmann, R., 2008, Using ALSM to map sinkholes in the urbanized covered karst of Pinellas County, Florida-1, methodological considerations: Environmental geology, v. 54, no. 5, p. 995-1005. https://doi.org/10.1007/s00254-007-0890-8.

Siart, C., Bubenzer, O., and Eitel, B., 2009, Combining digital elevation data (SRTM/ASTER), high resolution satellite imagery (Quickbird) and GIS for geomorphological mapping: A multi-component case study on Mediterranean karst in Central Crete: Geomorphology, v. 112, no. 1-2, p. 106-121. https://doi.org/10.1016/j.geomorph.2009.05.010.

Sowers, G.F., 1996, Building on sinkholes: design and construction of foundations in karst terrain, American Society of Civil Engineers. https:// doi.org/10.1061/9780784401767.

Spooner, J.D., and Kaufmann, J.E., 2007, Identifying the primary factors that determine the occurrence of sinkholes in the Ozarks, in Poster session presented at the annual meeting of the Geological Society of America, Denver, CO.

Stocks, L., 2007, Image-object analysis for sinkhole inventory, in Papers and Proceedings of Applied Geography Conferences, v. 30 , p. 447.

Stohr, C.J., Ivany, G.S., and Williams, J.H., 1981, Geologic aspects of hazardous-waste isolation in Missouri, Missouri Department of Natural Resources, Division of Geology and Land Survey, $55 \mathrm{p}$.

Taheri, K., Gutiérrez, F., Mohseni, H., Raeisi, E. and Taheri, M., 2015, Sinkhole susceptibility mapping using the analytical hierarchy process (AHP) and magnitude-frequency relationships: A case study in Hamadan province, Iran: Geomorphology, v. 234, p. 64-79. https://doi. org/10.1016/j.geomorph.2015.01.005.

Thomas, B., and Roth, M.J., 1999, Evaluation of site characterization methods for sinkholes in Pennsylvania and New Jersey: Engineering Geology, v. 52, no. 1-2, p. 147-152. https://doi.org/10.1016/S0013-7952(98)00068-4.

Troester, J.W., White, E.L., and White, W.B., 1984, A comparison of sinkhole depth frequency distributions in temperate and tropic karst regions, in Multidisciplinary Conference on Sinkholes, v. 1, p. 65-73.

USDA, 2011, Digital Elevation Model (DEM) Whitepaper, https://www.nrcs.usda.gov//nternet/FSE_DOCUMENTS/stelprdb1047930.pdf [accessed August 18, 2019].

Van Westen, C.J., Rengers, N., and Soeters, R., 2003, Use of geomorphological information in indirect landslide susceptibility assessment: Natural Hazards, v. 30, no. 3, p. 399-419. https://doi.org/10.1023/B:NHAZ.0000007097.42735.9e.

Van Westen, C.J., 2013, Remote sensing and GIS for natural hazards assessment and disaster risk management: Treatise on geomorphology, $v$. 3, p. 259-298. https://doi.org/10.1016/B978-0-12-374739-6.00051-8.

Wall, J., Bohnenstiehl, D.R., Wegmann, K.W., and Levine, N.S., 2017, Morphometric comparisons between automated and manual karst depression inventories in Apalachicola National Forest, Florida, and Mammoth Cave National Park, Kentucky, USA: Natural Hazards, v. 85, no. 2, p. 729-749. https://doi.org/10.1007/s11069-016-2600-x.

Weier, J., and Herring, D., 2000, Measuring Vegetation (NDVI \& EVI), https://earthobservatory.nasa.gov/features/MeasuringVegetation [accessed August 18, 2019].

Wu, S., Qiu, X., Usery, E.L., and Wang, L., 2009, Using geometrical, textural, and contextual information of land parcels for classification of detailed urban land use: Annals of the Association of American Geographers, v. 99, no. 1, p. 76-98. https://doi.org/10.1080/00045600802459 028..

Wu, S., Wang, L., and Qiu, X., 2008, Incorporating GIS building data and census housing statistics for sub-block-level population estimation: The Professional Geographer, v. 60, no. 1, p. 121-135. https://doi.org/10.1080/00330120701724251.

Zhou, W., and Beck, B.F., 2008, Management and mitigation of sinkholes on karst lands: an overview of practical applications: Environmental Geology, v. 55, no. 4, p. 837-851. https://doi.org/10.1007/s00254-007-1035-9.

Zhu, J., Taylor, T.P., Currens, J.C., and Crawford, M.M., 2014, Improved karst sinkhole mapping in Kentucky using LiDAR techniques: a pilot study in Floyds Fork Watershed: Journal of Cave and Karst Studies, v. 76, no. 3, p. 207. https://doi.org/10.4311/2013ES0135

Zisman, E.D., 2001, A standard method for sinkhole detection in the Tampa, Florida, area: Environmental \& Engineering Geoscience, v. 7, no. 1, p. 31-50. https://doi.org/10.2113/gseegeosci.7.1.31.

Zisman, E.D., 2008, A method of quantifying sinkhole risk, in Sinkholes and the Engineering and Environmental Impacts of Karst, p. $278-287$. https://doi.org/10.1061/41003(327)27..

Zumpano, V., Pisano, L., and Parise, M., 2019, An integrated framework to identify and analyze karst sinkholes: Geomorphology, v. 332, p. 213-225. https://doi.org/10.1016/j.geomorph.2019.02.013. 